166

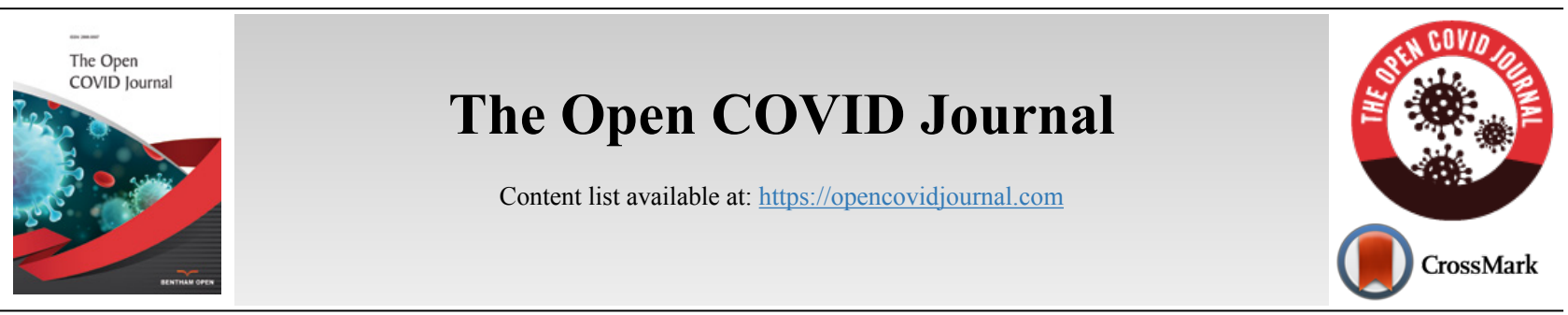

RESEARCH ARTICLE

\title{
Anti-COVID-19 Biomedicines - A Layout Proposal for Production, Storage and Transportation
}

Shibabrata Pattanayak ${ }^{1, *}$

${ }^{I}$ Department of Animal Resources Development, Govt. of West Bengal, Kolkata, India

\begin{abstract}
:
Background:

Modulation of non-specific immunity and other related activities of succulent parts of effective medicinal plants can prevent viral infections like COVID-19 through their dietary intake.

Objective:

The succulent parts of the medicinal plants with immunomodulation, anti-oxidation, anti-viral, anti-inflammatory, etc. power can be used orally in the capsular form to prevent as well as to reduce the severity of symptoms of COVID-19.

Methods:

A proposal is displayed with a detailed description of related steps like the selection of medicinal plant parts consulting related reports, collection of biomedicines, validation of efficacy, dosing, encapsulation, storage, and transportation, etc.

Results:

The succulent bio-medicines against COVID-19 can be developed and marketed following only some adoptive research.

Conclusion:

Succulent bio-medicines can be prepared and marketed for the prevention and cure of different infectious and non-infectious diseases.
\end{abstract}

Keywords: COVID-19, Succulent biomedicines, Immunomodulation, Prevention, Cure, Encapsulation.

\begin{tabular}{|l|l|l|l}
\hline Article History & Received: March 30, 2021 & Revised: June 21, 2021 & Accepted: June 22, 2021
\end{tabular}

\section{INTRODUCTION}

The novel Coronavirus (SARS-CoV-2) infection is causing huge morbidity and mortality in almost all the countries around the globe. The main symptoms of the disease are fever, sore throat, cough, chest pain, muscle pain, respiratory problems, headache, etc. which lead to further severity by causing respiratory insufficiency, affecting the vital organs like the heart, liver, kidney, nervous system, etc. and ultimately causing the death of many patients, particularly those having any previous co-morbidity [1].

For the diagnosis of this disease, some antigen testing procedures are available to detect the presence of the viral en-

* Address correspondence to this author at the Department of Animal Resources Development, Govt. of West Bengal, Kolkata, India.; Tel: (+91)9734823620; Email: pattanayak1966@gmail.com velop proteins from the nasopharyngeal fluids. But the main testing procedure used for this purpose is real-time Reverse Transcription-Polymerase Chain Reaction (RT-PCR) [2]. Other methods available are RT Loop-Mediated Isothermal Amplification (RT-LAMP) which is based on nanotechnology [2], detection of plasmonic meta-sensors even when lowmolecular-weight biomolecules are available at low densities, different modern techniques like toroidal meta-surface technology to diagnose the disease is also under study [1].

Antibodies against the COVID-19 viruses are detected from the serum mainly by enzyme-linked immunosorbent assay using a qualitative detection of IgG or IgM antibodies raised against the virus by the infected individuals at different time intervals [2].

Vaccination of the people and use of medicines like corticosteroids, antivirals, antibiotics, etc. are the procedures 
used presently to control the pandemic. Many synthetic drugs are tested for their efficacy and later rejected from the treatment schedule for not getting desirable or satisfactory effects [3].

The idea of using succulent parts of medicinal plants as bio-medicine is perhaps reverse to the concept of Modern medicine, which generally targets the development of the medicines synthetically. The contemporary Ayurvedic medicines available in the market and almost all other medicines prepared using herbal sources use mostly the dried parts of medicinal plants. Drying and all other processing procedures generally negatively affect the bio-availability of the phytoconstituents actually present in any part of a living plant, both in consideration of number, quantity and quality [4, 5]. Boiling of the medicinal plant parts to prepare decoctions has the same type of limitations [5 - 7].

For initiation and maintenance of different infectious as well as non-infectious diseases, the effect of lifestyle-related factors can never be neglected. The 'permitted' synthetic chemicals and known toxic chemicals of different names and categories that enter inside our body system may act cumulatively and so can reduce the normal disease preventive power of the body. That can accelerate or trigger the genetic predisposition and/ or catching as well as the spread of different diseases $[6,7]$.

Removal of cause and curing of the effects is the target of all therapies. For COVID-19, a viral disease, the same can be considered as true. The succulent biomedicines can be a good option for the prevention of that disease, reduction of disease symptoms, and restoration of health after recovery. So, they can act as curative in one hand and as masking agents on untoward effects of genetic predisposition in the other. Diet is also one important factor. Nutrients available to the body from the diet in pre-disease, disease, and post disease conditions of COVID-19 can also influence the disease condition [8].

\section{MATERIALS AND METHODS}

The present research deals with the framing of a system to produce and use succulent biomedicines to control COVID-19 and alike diseases. Under the methodology of the research, the following points are covered.

i) Identification of the therapeutic concepts for the control of the disease by use of succulent biomedicines.

ii) Survey of the medicinal plants having report/s to influence COVID-19 and alike diseases and/ or symptoms.

iii) Selection of some plants for use of their parts at therapeutic purposes to prevent the disease.

iv) Chalking out of different steps for production and use of the biomedicines.

\section{RESULTS AND DISCUSSION}

\subsection{Identification of the Therapeutic Concepts for Control of the Disease by use of Succulent Biomedicines}

\subsubsection{Concept of Succulent Biomedicines and their use to Control Diseases like COVID-19}

The succulent biomedicines can perform their activities inside the body system in different ways. They can act directly on the invading microorganisms, as on their growth, multiplication, and spread. They can also work by modulating different arms of the immunity system of the body [9]. Prevention of catching the infections, reduction of severity of the symptoms, and triggering or masking of the genetic predisposition of an individual may have a tremendous effect on the overall disease. The concept of the use of succulent biomedicines to control different diseases is having some other important areas that require separate analysis to determine the possible effects of these medicines on the overall physiological system [9].

\subsubsection{The Cumulative Effect Concept}

Contemporary researches performed for the validation of effects of plant parts as medicine are mainly or solely target identification of the active principles to synthesize them chemically to market as medicines. Such research is linked with the development of new drugs for Modern medicine.

Almost all the contemporary Alternative Healthcare Systems related with the use of part of herbs directly as medicines generally use the dried plant parts or their chemical extracts or decoctions, singly or at poly-herbal formulations.

Every medicinal plant part contains thousands of phytochemicals. In the succulent condition, all of them get the opportunity to show their activity together. But many phytochemicals of the succulent parts of medicinal plants are definitely absent or reduced in quantity in the dry form or any other processed form due to evaporation and chemical changes related to the drying or boiling procedures. In the solvent extracted portions of the dry plant parts (performed in contemporary research for drug development), only a portion of the phytoconstituents present in the dry part of the medicinal plants is extracted. Therefore, we cannot get any idea about the lost phytochemicals which were actually present in the succulent parts of plants through contemporary methods. But those may have some important effects on our health (as fruits are eaten in succulent condition to get maximum benefits) $[7$, $10]$.

The succulent bio-medicines are not having any such limitations, as they can show the cumulative effect of all phytochemicals present in the parts of medicinal plants.

\subsubsection{Modulation of Non-specific Immunity}

The succulent bio-medicines are having Immunomodulation, Anti-oxidation, Antiviral and/or many other related effects. They can exert such effects through the diverse number of phytochemicals present among them.

\subsubsection{Anti-Oxidation Activity of Plant Medicines}

Nature gifted us many antioxidants in different fruits and vegetables, spices, and in many medicinal plants at their succulent stage. Along with drying, frying, and boiling at high temperatures, many of them reduce in quantity to a large extent.

Oxygen acts as the terminal acceptor of the electron during aerobic metabolism. That oxygen then splits into single atoms 
with an unpaired electron and thus seeks another electron to be paired. Such single atom oxygen is termed as free radicals and the scavenging activity of these free radicals can cause many detrimental health effects inside the body. If such activities are not controlled by the supply of antioxidants, damage or disruption of different cellular bio-molecules will be there through the production of different Reactive Oxygen Species (ROS) [11]. By incurring negative influences on different important aspects of the body like signal transduction system of the body, expression of the gene of individuals, inactivating different receptors, influencing the immune system, acting on nuclear transcription factors, aging, cytotoxic activities, etc., these can cause severe harmful effects in the overall body system which may lead to easy transmission of infections and showing more severity in the expression of disease symptoms $[12,13]$.

The antioxidants can prevent these detrimental processes or can slow down these by removing the free radicals, thus can protect us from various diseases.

Carotenoids (nearly 1000 are known) and Phenolic compounds (identified over 400 flavonoids, more than 8000 plant phenols, Benzoic acid derivatives; proanthocyanins, stilbenes, coumarins, lignans, lignin, etc.) are some well-known antioxidants $[12,14]$.

The dietary intake of a single antioxidant even in large quantity is not profitable. Regular intake of different antioxidants is the only way to get the best benefit from them [12].

Many antioxidants are present in edible vegetable items (like succulent fruits, vegetables, etc.). Selective use of succulent biomedicines can supply particular antioxidants to control the targeted adverse effects and reactions of the oxidants inside the body [10]

\subsubsection{Immunomodulation Activities}

The stimulatory or suppressive activities of the dietary supplied phytochemicals on the immunity system of the body can influence the health status of an individual to a large extent [15]. Such modulation of immunity power can increase the body resistance by influencing the cells and the mediators of the system and can prevent various infections. An increase of the abilities like oxidative activities of blood neutrophils, phagocytic power of the cells of microphase lineage, activities of the cytotoxic $\mathrm{T}$ lymphocytes to destroy virus-infected cells or cancer cells, etc. can assist in such works. Control of excessive activities of some cells is also very important for the prevention and cure of dangerous diseases like hypersensitivity diseases $[9,16]$.

The succulent biomedicines can act at various different areas of the immune system. These include antigen recognition and phagocytosis, lymphocyte proliferation and differentiation, synthesis of antibodies, interactions of antibodies with antigen, the release of biochemical mediators of the immune response, control of autoimmune diseases, modification of target tissue response and target effector organs, influence on apoptosis by affecting the programmed cell death, influence on the complement system of the body etc [17 - 19].

\subsubsection{Antiviral Effects}

Metabolites of the dietary taken succulent biomedicines can work against invading viruses in various ways. It may be through modulation of different arms and parameters of immunity system of the body or by incurring direct effects on replication and spread of the virus, expression of the disease symptoms, effect on the killing of virus-infected cells by the Cytotoxic T lymphocytes etc [9].

\subsubsection{Other Related Effects}

Activities as control of different co-morbidities like diabetes, hypertension, arteriosclerosis, obesity, improper liver or kidney function, problems of the gastrointestinal system, etc. can definitely influence the body immunity and can also affect the catching of infections and development of diseases like COVID-19. Many succulent biomedicines are having additional powers to control such co-morbidities and also cure the related problems [9].

\subsubsection{Use as Some Preventive Medicines}

The succulent biomedicines can also supply many additional benefits in different health problems. These can be used as preventive medicines for different infections at the individual level, for the susceptible population in epidemic conditions, during as well as after recovery of many infections. They can be effectively used along with vaccination and also during allopathic medication of devastating diseases like cancers. To modulate overall body immunity, these can also be used for a few days before and after any major surgery.

Many reports are available for possible health impacts of herbal medicines as anti-aging [20], hepatoprotective [21], radioprotective [22], etc. In many cases, such effects are interlinked and one succulent biomedicine can show more than one type of positive health effect [9].

\subsubsection{Negligible Chance of Development of Resistance by the Invading Organisms}

As the number of total phytoconstituents even in a single bio-medicine maybe some thousands in number (maybe multiplied to some folds when a few such medicines are used together), and they are supposed to act on the different receptors of the body system and can also modulate the synthesis and activities of different cytokines following different ways along with other effects (mechanism of actions), so there may be practically no chance for the building of resistance against all of them by the organisms like COVID-19 virus [9].

\subsubsection{Supply of Important Micronutrients}

The succulent bio-medicines can also supply almost allimportant natural micronutrients (Vitamins, Minerals, etc.) along with other phytochemicals, which are generally absent in processed and fried foods. People of contemporary generations are adopted in eating such foods. This may be an additional benefit of the use of such bio-medicines to all of them [7]. 
3.2. Survey of the Medicinal Plants having Report to Influence COVID-19 and alike Diseases and/ or Symptoms

\subsubsection{Parameters for Selection of Medicinal Plants having the Power to Control COVID-19}

Succulent parts of medicinal plants can work against the COVID-19 virus in various ways together. The abilities like modification of various parameters related with Innate or Nonspecific immunity - antioxidation, immunomodulation, antiinflammatory, analgesic, antipyretic, etc. activities; protective actions on the respiratory system, cardiovascular system, etc. are important. Other activities like anti-diabetic, anticholesteric, hepato-protective, reno-protective, etc. actions are also not less important. Such activities of that type of plantderived bio-medicines are considered along with direct antiviral and other antimicrobial effects [5, 7, 9]. One important difference between such succulent bio-medicines with Modern medicines is that even a single bio-medicine may show many of these stated activities together. It can be easily imagined that the cumulative activities of a few of such biomedicines may be very diverse and strong to bring desirable effects (Fig. 1).

\subsubsection{Identification of the Medicinal Plants with Anti- COVID-19 Activities}

Many articles are surveyed for searching of medicinal plants with desired activities. Some reports are available with possible antiviral activities of the medicinal plant parts. The name of 1060 plants having a report of controlling and combating infectious diseases was a good source article for the collection of related plants [23]. The name of 78 plants with related activities is described in another publication [10]. Another list of 130 plants with reports of immunomodulation to control and cure diseases [9] is also considered.

\subsection{Selection of some Plants for use of their Parts at Therapeutic Purposes to Prevent the Disease}

\subsubsection{Selection of the Medicinal Plants}

Many plants are having the power to act directly or indirectly against initiation, spread, and expression of disease symptoms of viral infections like COVID-19. Among such plants, many plants are well known to the research community for years and there are many plants that are already in use by the common people at different forms in many other purposes, but generally not used orally in succulent form as some medicines (Fig. 2).

Considering all the available resources, 25 plants are selected for the preparation of succulent biomedicines from them at the present primary level effort with an expectation of nil or negligible toxicity in their oral therapeutic doses and available study reports of their efficacy possibly related with COVID-19. As it is a proposal for the development of biomedicines at the primary level, only such a small number of plants are considered. However, each and every medicinal plant having a report of related efficacies may be considered for the same type of study in the future.

The already identified related effects of the selected medicinal plants are added for each of these 25 medicinal plants in the following section. As the study report on succulent parts of medicinal plants or their juices/ seed powders etc. is scarce, the available records, mainly the activity study of the solvent extracted portion of dry plant parts or isolated phytochemicals or the previous reports of the use of medicinal plant parts for related purposes are added for each medicinal plant (Fig. 3).

\subsubsection{Indication, Doses, etc.}

The proposed indication, doses, etc. added against each plant are just to express some idea about these points and in no case, these are to be considered as final. The combinational use schedule of the biomedicines for preventive, curative, as well as at post disease conditions also requires some adoptive research before finalization (Figs. 4 and 5).

\subsubsection{List of Medicinal Plants having the Ability to Control COVID-19}

The selected medicinal plants with the ability to control viral infections like COVID-19 are listed. The name of the plants with Family, previous related research findings, and other details are collected and added for each plant. The name of the plants is added following the order of English letters. Photographs of the plants are added in Fig. (1).

\subsubsection{Adhatoda Vasica Nees}

Family: Acanthaceae

Related previous reports:

Antioxidant [24 - 26], Immunomodulant [26 - 28], Antiviral [26, 29, 30], Antimicrobial [24, 26, 31], Cardioprotective [26, 31], Anti-cholinesterase [31], Bronchodilator [32], Antiinflammatory [26, 31], Hepatoprotective, Antidiabetic, Thrombolytic [26].

\section{Indications:}

(a) Part of the plant to be used: Succulent leaf.

(b) Proposed form of use: Paste/ pressure extract.

(c) Use: 3 -7 days in a week as per requirement. adults.

(d) Proposed dose: May be within 3-5 grams per dose for

\subsubsection{Allium Sativum L.}

Family: Amaryllidaceae

Related previous reports:

Antioxidant [33 - 35], Immunomodulant [36 - 38], Anticancer [35, 37, 39], Antiviral [36, 40, 41], Antiinflammatory, Anti-microbial, Cardioprotective [35 - 37], control Respiratory infections, Tuberculosis, Duodenal ulcer [42].

\section{Indications:}

(a) Part of the plant to be used: Succulent bulb.

(b) Proposed form of use: Paste/pressure extract.

(c) Use: Daily. 
(d) Proposed dose: 4-6 grams bulb paste for adults.

\subsubsection{Andrographis paniculata (Burm.f.) Nees}

Family: Acanthaceae

Related previous reports:

Antioxidant [43 - 45], Immunomodulant [46 - 48], Antiviral [47, 49, 50], Anticancer [44], Anti-Inflammatory [44, 48], Hepatoprotective, Antimicrobial, Antipyretic, Analgesic, Antimalarial, Antihyperglycemic, positive effects on cardiovascular diseases, inhibitory effects on Platelet aggregation [44]; in Influenza, Bronchitis [42].

Indications:

(a) Part of the plant to be used: Succulent leaf.

(b) Proposed form of use: Paste/ pressure extract.

(c) Use: 1-2 days in a week, preferably at empty stomach (morning), abstaining foods for next one hour.

(d) Proposed dose: 2-3 grams of leaves per dose for adults.

\section{$\underline{\text { 3.3.3.4. Azadirachta indica A. Juss }}$}

Family: Meliaceae

Related previous reports:

Antioxidant [51 - 53], Immunomodulant [51, 54, 55], Antiviral [51, 56, 57]; Antibacterial, Antifungal, Antiinflammatory [51].

Indications:

(a) Part of the plant to be used: Succulent leaf.

(b) Proposed form of use: Paste/ pressure extract.

(c) Use: 3-5 days in a week.

(d) Proposed dose: May be within 3-5 grams per dose for adults.

\subsubsection{Chlorophytum borivilianum Santapau \& R.R. Fern}

Family: Asparagaceae

Related previous reports:

Antioxidant [58 - 60], Immunomodulant [61 - 63], Antiviral [64], Anticancer [60, 63], Antidiabetic [60, 61, 63], Antimicrobial [60, 63], Anti-inflammatory [58], Analgesic [60, 61], Antistress [60, 61, 63], Hyper-cholesteraemic [60, 61], Antiulcer [60, 63], Aphrodisiac [60, 61, 63].

Indications:

(d) Part of the plant to be used: Succulent root.

(b) Proposed form of use: Paste/ pressure extract.

(c) Use: 3-5 days in a week.

(d) Proposed dose: May be within 10-15 grams per dose for adults.

\subsubsection{Citrous limon}

Family: Rutaceae

Related previous reports:
Antioxidant [65 - 67], Antiviral and Antimicrobial [66, 68, 69], Immunomodulant [70, 71], Anti-inflammatory [66, 68], Anticancer [66, 68, 72], Anti-allergic [66], Hepatoregenerating effect [66, 73], Antidiabetic [66, 74]; having various positive effects on Cardio-vascular Respiratory, Nervous and Skeletal system [66]; can bring down Fever and balance $\mathrm{pH}[72]$.

Indications:

(a) Part of the plant to be used: Fruit.

(b) Proposed form of use: Pressure extracts (Juice).

(c) Use: Daily in morning, mixing with lukewarm water.

(d) Proposed dose: May be within 50 - 100 drops for adults.

\subsubsection{Curcuma longa $L$.}

Family: Zingiberaceae

Related previous reports:

Antioxidant [75 - 77], Immunomodulant [78 - 80], Anticancer [77, 81], Antiviral [82 - 84]; Anti-inflammatory, Antibacterial, Antifungal, Antidiabetic, Anticoagulant, Cardiovascular protective, Hepatoprotective [77].

Indications:

(a) Part of the plant to be used: Succulent rhizome.

(b) Proposed form of use: Pulp/pressure extract.

(c) Use: May be daily in the morning at an empty stomach for 5 days in a week.

(d) Proposed dose: May be within 5-10 grams for adults.

\subsubsection{Daucus carota $L$}

Family: Apiaceae

Related previous reports:

Antioxidant [85 - 87], Anticancer [86, 87], Immunomodulant [86], Antiviral [88, 89], seed antiviral [90]; Antimicrobial, Smooth muscle relaxant [91]; Anti-diabetic, Cholesterol and Cardiovascular disease protecting, Antihypertensive, Hepatoprotective, Reno-protective etc [86, 87].

Indications:

(a) Part of the plant to be used: Succulent root.

(b) Proposed form of use: Pulp/pressure extract.

(c) Use: For 5-7 days in a week.

(d) Proposed dose: May be within 5-10 grams for adults.

\subsubsection{Emblica officinalis Gaertn}

Family: Phyllanthaceae

Related previous reports:

Antioxidant [92 - 94], Immunomodulant [92 - 94], Antiviral [94 - 96], Anticarcinogenic [92, 93, 95], Antipyretic, in Cold and Fever, Analgesic, Anti-inflammatory, Antitussive, Antiatherogenic, Adaptogenic, Cardioprotective, 
Gastroprotective, Anti-anemic, Anti-hypercholesterolemic, Antidiarrheal, Anti-atherosclerotic, Hepatoprotective, Nephroprotective, Neuroprotective properties [92, 93], Antimicrobial, Antidiabetic, Antiulcerogenic [93, 95].

Indications:

(a) Part of the plant to be used: Succulent fruit.

(b) Proposed form of use: Pulp/pressure extract.

(c) Use: Daily.

(d) Proposed dose: 5-6 grams of pulp for adults.

\subsubsection{Hibiscus sabdariffa $L$.}

Family: Malvaceae

Related previous reports:

Antioxidant [96 - 99], Immunomodulant [100 - 102], Antiviral [103 - 105], Anticancer, Hepatoprotective, Nephroprotective, Antibacterial, Renal/Diuretic effect, Antipyretic, Anti-inflammatory, Anti-cholesterol, Antidiabetic, Anti-hypertensive, Anti-obesity, Anti-anemic activities [98].

Indications:

(a) Part of the plant to be used: Succulent leaves and petals over fruits.

(b) Proposed form of use: Paste/pressure extract.

(c) Use: Daily in the afternoon.

(d) Proposed dose: Extract of 5-10 leaves per dose for adults.

\subsubsection{Moringa oleifera Lam.}

Family: Moringaceae

Related previous reports:

Antioxidant (leaf- [106 - 108]; pod - [109]), Immunomodulant (leaf - [110 - 112]; flower - [113]), Antiviral (leaf - [57, 114, 115]; seed - [116]), Anti-inflammatory (leaf[108]), Anti-diabetes (pod- [109]); Leaf in High blood pressure, root as Antimicrobial and as Preservative [113].

Indications:

(a) Part of the plant to be used: Leaf and/or flower.

(b) Proposed form of use: Paste/ pressure extract.

(c) Use: 5 days in a week.

(d) Proposed dose: May be within 5-6 grams per dose for adults.

\subsubsection{Nigella sativa $L$.}

Family: Ranunculaceae

Related previous reports:

Antioxidant [117 - 119], Immunomodulant [117, 120, 121], Antiviral [122 - 124], Anticancer [117, 125, 126], Hepatoprotective [117, 127, 128], Antidiabetic, Analgesic, Anti-inflammatory, Antimicrobial, Spasmolytic,
Bronchodilator, Anti-hypertensive, Renal protective [117]. Indications:

(a) Part of the plant to be used: Seed.

(b) Proposed form of use: Paste/ powder.

(c) Use: 5 days in a week.

(d) Proposed dose: May be within 3-5 grams per dose for adults.

\subsubsection{Ocimum sanctum $L$.}

Family: Lamiaceae

Related previous reports:

Antioxidant [129 - 131], Immunomodulant [132 - 134], Antiviral [135 - 137]; in Influenza, Common cold, Cough, Headache, Fever, Bronchitis, Asthma, Hepatic diseases, Fatigue [138]; Hypoglycemic, Hypolipidemic effects [129].

Indications:

(a) Part of the plant to be used: Succulent leaf.

(b) Proposed form of use: Pressure extract.

(c) Use: In the morning.

(d) Proposed dose: Extract of 10 - 20 leaves.

\subsubsection{Pimenta dioica (L.) Merr.}

Family: Myrtaceae

Related previous reports:

Antioxidant [139 - 141], Immunomodulant [142 - 144], Anticancer [139, 142, 144], Antiviral [145], Antidiabetic [139], Antimicrobial [139, 141, 142]; Hypotensive, Anti-neuralgic, Analgesic [142].

Indications:

(a) Part of the plant to be used: Dry berries.

(b) Proposed form of use: Powder.

(c) Use: 5 days in a week. adults.

(d) Proposed dose: May be within 3-5 grams per dose for

\subsubsection{Piper longum $L$.}

Family: Piperaceae

Related previous reports:

Antioxidant [146 - 148], Immunomodulant [148 - 150], Antiviral [150], Anticancer/ Anti-tumor [148, 150, 151], Hepatoprotective [148 - 150], Antidiabetic [148], Antimicrobial, Antiplatelet, Antihyperlipidemic, Analgesic, induce Coronary vasodilation, Cardioprotective; act to correct chronic Bronchitis, Asthma, viral Hepatitis, Respiratory infections [149, 150], diseases of the Respiratory tract [42].

Indications:

(a) Part of the plant to be used: Berries.

(b) Proposed form of use: Paste/pressure extract. 
(c) Use: Daily in the afternoon for 5 days in a week.

(d) Proposed dose: May be within 4-6 grams for adults.

\subsubsection{Piper nigrum $L$.}

Family: Piperaceae

Related previous reports:

Antioxidant [152 - 154], Immunomodulant [154 - 156], Antiviral [151, 157, 158], Anticancer [153, 151, 154], Hepatoprotective [153, 154], Antihypertensive, Antiplatelet, Anti-asthmatics, Analgesic, Anti-inflammatory, Anti-diarrheal, Antispasmodic, Antidepressants, Anticonvulsant, Antibacterial, Antifungal [153], in Cough, Sinusitis [113].

Indications:

(a) Part of the plant to be used: Dry seed.

(b) Proposed form of use: Powder.

(c) Use: At afternoon for 5 days in a week.

(d) Proposed dose: 5-6 seeds per dose in adults.

\subsubsection{Rosmarinus officinalis $L$.}

Family: Lamiaceae

Related previous reports:

Antioxidant [159 - 161], Immunomodulant [162 - 164], Antiviral [114, 165], Antimicrobial [159], Hepatoprotective [160] etc.

Indications:

(a) Part of the plant to be used: Succulent leaf.

(b) Proposed form of use: Paste/ pressure extract.

(c) Use: 5 days in a week.

(d) Proposed dose: May be within 3-5 grams per dose for adults.

\subsubsection{Taraxacum Officinale (L.) Weber ex F.H. Wigg.}

Family: Asteraceae

Related previous reports:

Antioxidant [166 - 168], Immunomodulant [169 - 171], Antiviral [172 - 174], Anticancer [166, 175], Antidiabetic [171], Anti-lipidemic [167], Anti-inflammatory, Diuretic, Analgesic, Anti-hyperglycemic, Anticoagulatory, Prebiotic effects; Spleen and Liver protective [166]; active in Obesity, Hepatitis, Arthritis, Cardiovascular diseases [175].

Indications:

(a) Part of the plant to be used: Whole plant.

(b) Proposed form of use: Paste/ pressure extract.

(c) Use: 5 days in a week.

(d) Proposed dose: May be within 3-5 grams per dose for adults.

\subsubsection{Terminalia Chebula Retz.}

Family: Combretaceae
Related previous reports:

Antioxidant [176 - 178], Immunomodulant [179 - 181], Antiviral [182 - 184], Anticancer [185], Analgesic [178]; Antimicrobial, Antidiabetic. Cardioprotective, Hypocholesterolemic, Adaptogenic and Anti-anaphylactic, Hepatoprotective [185]; in Kidney and Liver problems; having Antitussive, Homeostatic, Diuretic, Laxative effects [181].

Indications:

(a) Part of the plant to be used: Dried fruit.

(b) Proposed form of use: Powder of the dried pulp.

(c) Use: 3-4 days in a week. adults.

(d) Proposed dose: May be within 3-5 grams per dose for

\subsubsection{Thymus Vulgaris $L$.}

Family: Lamiaceae

Related previous reports:

Antioxidant [186 - 188], Immunomodulant [189 - 191], Antiviral [192 - 194], Antimicrobial [188, 195] etc.

Indications:

(a) Part of the plant to be used: Succulent leaf.

(b) Proposed form of use: Paste/ pressure extract.

(c) Use: 3 days in a week.

(d) Proposed dose: May be within 3-5 grams per dose for adults.

\subsubsection{Tinospora Cordifolia (Thunb.) Miers.}

Family: Menispermaceae

Related previous reports:

Antioxidant [196 - 198] Immunomodulant [199 - 201], Antiviral [202, 203], in Kidney and Liver problems, having Antitussive, Cardiotonic, Homeostatic, Diuretic etc. effects [181].

Indications:

(a) Part of the plant to be used: Succulent stem.

(b) Proposed form of use: Paste/ pressure extract.

(c) Use: 3-5 days in a week. adults.

(d) Proposed dose: May be within 3-5 grams per dose for

\subsubsection{Vaccinium Corymbosum L.}

Family: Ericaceae

Related previous reports:

Antioxidant [204 - 206], Immunomodulant [206, 207], Antiviral [208], Anticancer [208], Anti- diabetes [206, 208], Anti-inflammatory [204, 206], active against Circulatory disorder [208], Hypercholesterolemia and Hypertension [206].

Indications:

(a) Part of the plant to be used: Ripe fruit 
(b) Proposed form of use: Pulp paste/ pressure extract.

(c) Use: May be daily.

(d) Proposed dose: May be 20-25 grams per dose for adults.

\subsubsection{Vernonia amygdalina Delile.}

Family: Asteraceae

Related previous reports:

Antioxidant [209 - 211], Immunomodulant [212 - 214], Antiviral [215, 216], Anticancer [210, 215, 217]; Anti-diabetic, Liver protective, Anti-allergic, Anti-inflammatory, Antimicrobial, Anti-malaria, Anti-leukemia [215, 217].

Indications:

(a) Part of the plant to be used: Succulent shoot and leaf.

(b) Proposed form of use: Paste/ pressure extract.

(c) Use: 3-4 days in a week.

(d) Proposed dose: May be within 3-5 grams per dose for adults.

\subsubsection{Withania Somnifera (L.) Dunal.}

Family: Solanaceae

Related previous reports:

Antioxidant [218 - 220], Immunomodulant [221 - 223], Antiviral [224 - 226], Anticancer [221, 227], Antimicrobial [218, 221], Anti-inflammatory [221, 228]; Hypolipidemic, Cardiovascular protection, Anti-stress, assist in Hematopoiesis [221].

Indications:

(a) Part of the plant to be used: Root.

(b) Proposed form of use: Paste.

(c) Use: 3-5 days in a week.

(d) Proposed dose: May be within 2-3 grams per dose for adults.

\subsubsection{Zingiber officinale Roscoe.}

Family: Zingiberaceae

Related previous reports:

Antioxidant [42, 229, 230], Immunostimulant [231 - 233], Anticancer [234 - 236], Antiviral [237 - 239], Hepatoprotective [240], Respiratory protective, Anti-inflammatory, Antidiabetic, Antimicrobial, Neuroprotective, Cardiovascular protective, Anti-obesity, Antinausea, Antiemetic activities [230].

Indications:

(a) Part of the plant to be used: Succulent rhizome.

(b) Proposed form of use: Pulp/pressure extract.

(c) Use: Normal - once daily for 3 days in a week; thrice daily in patients with involvement of respiratory organs.

(d) Proposed dose: 2-3 grams pulp per dose for adults.

\subsection{Chalking out of Different Steps for Production and use of the Biomedicines}

Different steps are studied for validation of reported activities, collection of the proper parts of the medicinal plants, production of succulent biomedicines from them and their transportation up to the patient level.

\subsubsection{Validation of Claimed Activities}

For validation of the reported activities of the medicinal plants to control viral infections like COVID-19, the in vivo studies of the succulent parts of the medicinal plants may be given preference.

There are many reports available regarding the presence of the identifiable phytochemicals in the solvent extracted section of the dry parts of the listed medicinal plants. Studies on the effects of the identified phytochemicals are generally performed in contemporary phytomedicine research throughout the globe for identification of active principle/s principally with an intention of synthetically producing them to market as Modern medicine.

The present concept related with the novel proposal of development of succulent biomedicines is out of that contemporary research idea.

As per the new concept, related studies to find out and/or prove the effects and abilities of the succulent parts of the reported medicinal plants with an intention to market them directly as medicines (rather than identification of phytochemicals present among them) may be given preference. The logic behind the present concept is that many phytochemicals may be volatile in nature or may be present in very minute, undetectable amounts in the succulent biomedicines (and may be absent in diluents-extracted sections of dry medicinal plant parts). But these may have very good effects on our health. So, it will be a better option to study the cumulative effects (total effects) of all phytoconstituents present in the succulent bio-medicines preferably in vivo [7].

The already developed and available techniques/procedures to perform the related studies in contemporary research may be adopted for that purpose also with some required modification/s.

\subsubsection{Constraints in the Validation Process and the Possible Solutions}

Identification of the mechanism of actions of medicines of synthetic or semi-synthetic origin used in Modern medicine is presently at a more or less established stage due to intense study performed by many dedicated scientists and research workers and addition, alteration, and other modifications of the ideas and procedures continuously by them.

But it is not so easy to identify and establish the mechanism of actions of the succulent biomedicines even by using the modern techniques.

There are several reasons behind it.

(i) The medicines of synthetic origin (used in Modern medicine - the 'drugs') act as a single molecule most of the 
time. The succulent herbs may contain several molecules; some of them are so negligible in amount (though may be a source of very strong effects) that they may remain below the level of detection even during use of the latest techniques available in modern analytical science.

(ii) It is easy to follow a single drug from its ingestion up to the excretion from the body system. But it cannot be said for succulent bio-medicines, as their activities are like the ingested succulent fruits.

(iii) Involvement of receptors of the body system may be far more complex in the activity study of biomedicines due to the same reason of presence of a huge number of phytochemicals of different amounts.

(iv) The metabolic products of the huge number of phytochemicals present in a single bio-medicine may be very diverse and so it may be very difficult to identify all of them and then to perform further studies on them.

(v) The concept of study of synthetic medicines may not be applicable to study the biomedicines in many cases due to the fact that some components of the biomedicines may not show their effect instantly. They may act slow or very slow in our system.

(vi) As the metabolic products of the phyto-constituents taken orally through succulent bio-medicines (like the edible fruits taken at succulent stage) work actually inside our body system, so emphasis may be given to the effect of metabolic products of such medicines, not on the phytochemicals isolated in the laboratories only.

(vii) Positive actions of some components of succulent biomedicines may be compared with the detrimental effects of the xenobiotic residues and/or adulterated toxic chemicals enter our body for their activity mechanism, as both of these groups can act very slowly and actually the cumulative effect of all of them is expressed ultimately.

So, the validation processes for reported activities of succulent bio-medicines need to be different from those applied in Modern medicine.

The presently available techniques/ procedures directed towards the study of activities of single molecules may be modified with a direction to study the cumulative action of all the phytochemicals present in the bio-medicines, if required.

Shifting to a new concept can solve these problems, as displayed in Fig. (2).

\subsubsection{Study for Toxicity and Dose}

It can be performed following conventional procedures already developed and followed in Modern Medicine with some modifications, if required.

For succulent biomedicines, one important point related to the calculation of doses is that the availability of effective phytoconstituents is not constant in the raw materials obtained from different sources/ times. It is variable with the factors like the type of soil, stage of growth of the plant, temperature, humidity, and other related factors of the area during cultivation of the plant etc.
The presence of main phytoconstituents in each batch of raw materials may be matched with a standard chart (can be prepared using available resources) before calculation of individual doses.

All the selected twenty-five plants are expected to have no toxicity at therapeutic doses. However, among all the biomedicines listed, some are regularly consumed by many people in different purposes (plant numbers 2, 6, 7, 8, 9, 10, 11, 12, $13,14,15,16,19,22,25)$. So, these perhaps do not require any vigorous study of toxicity. Other plants may require to some extent rigid toxicity study.

\subsubsection{Production of Succulent Bio-medicines}

Different steps related to the production of succulent biomedicines for COVID-19 is discussed in the following paragraphs. A flow diagram of all the related procedures is displayed in Fig. (3).

\subsubsection{Collection of Materials}

Cultivation of the medicinal plants may be arranged at their natural or near-natural soil and environment. It will be the best option to perform Organic Farming of these plants. Adulteration of plant parts by the supplier may be a dangerous problem, so proper care should be taken in the whole process, from the cultivation of plants and collection of raw materials up to their transportation to the industry $[5,7]$.

The plant materials may be collected by hands covered by sterile gloves or by use of any mechanical means. Then the materials may be washed by germ-free water and then by distilled water. These may be soaked in salt, vinegar, baking soda, and lemon juice prior to preservation as per specific requirements [241].

Washing by of $70 \%$ Ethyl alcohol may be performed to control the vegetative microorganisms of the surface of the plant parts [7].

The surface of the fruit, root, leaves, etc. may require mechanical removal of adhered dust and other materials. Sterile absorbable cotton soaked with 70\% Ethyl alcohol may be used to clean them. Potassium permanganate, Alum, Sodium bicarbonate, Lime water, etc. chemicals may be used for such primary washing as per specific requirements [7].

After such washing, a final thorough washing by distilled water (of normal room temperature, lukewarm temperature, or hot water as per the requirement) may be required. Then the materials may be kept under the shade with the flow of dustfree and germ-free air (as performed in laminar flow system) for removal of adhered water droplets.

\subsubsection{Collection of Cut Pieces, Pastes and Juices from Succulent Plant Parts}

The external cover of the cleaned plant parts (of fruits, roots, stems, etc.) may be removed by proper sterile sharp instruments or by other efficient mechanical means. The materials may be divided into some pieces by sterile instruments. As per the requirements, removal of seed, pulp, hard parts, etc. maybe performed in a germ-free environment. 
The materials may be converted to paste by any mechanical means using proper instruments as performed on a small scale by Mixture and Grinder. The juices may be extracted out by applying mechanical pressure using proper instruments. Filtration of the materials may be required in some cases. The cut pieces, pulps, juices, etc. may be kept at low temperatures $\left(\right.$ as $0^{\circ} \mathrm{C}$ ) or at freezing temperatures (below $0^{\circ} \mathrm{C}$ ) before use at the next specific purpose/s [7].

\subsubsection{Conversion of Dry Seeds to Powder}

The dry seeds or dry fruits may be converted to fine dust by taking appropriate machinery assistance as per the requirements.

\subsubsection{Individual Dosing of the Medicines and their use}

(i) Proposed pattern of use of medicines: Some medicines may be used almost in the routine purpose for the modulation of body immunity and other activities. Some others may be used in diseased conditions and some others for specialized purposes. Preparation of indications for use of the bio-medicines also requires some study before standardization.

(ii) Pattern of dosing of bio-medicines: In the list of twenty-five selected plants, proposed use pattern and dosing are added. The approximate weight of the raw bio-material (leaf, pulp, etc.) is added there. As these dosing etc. are all speculative in nature, some adoptive research is required in these areas also. Research is also required for the use of medicines for definite purposes - as some may be used regularly by immune-compromised patients/ elderly patients, some during pandemics, etc.

\subsubsection{Preservation of the Succulent Bio-medicines}

Man uses succulent part of the plants (fruits, leaves, roots, etc. of many plants) as some source of many important nutrients, micronutrients, or medicines from a very ancient day. Use of dry parts of the plants at required purposes were developed due to many reasons, perhaps mainly for nonavailability of them throughout the year and for their spoilage during storage and transportation.

Afterward, a technique for the addition of different germicidal chemicals in the extracted juices of fruits, etc., and liquid/ semisolid/ tablet presentation of the dry powders of the medicinal plant parts after mixing with some germicides was developed to overcome these problems (the preservatives). Along with these, some other chemicals were also added without any scientific reason, perhaps just to attract the consumers (the added flavor, color, etc.). The cumulative effects of all these chemicals in continuous use cannot be considered as undoubtedly safe for our health [7].

In the field of herbal medicines, the dry parts of the medicinal plants are mainly used. The dry powders are used in liquid form after mixing with ethyl alcohol and/ or some other germicidal materials. Other forms like semisolid or tablet presentation of the dry powders of the medicinal plant parts with or without vehicle materials were also in practice. Boiling of one or a few herbal plant parts/s to prepare decoction is another practice.
In all such cases, the main reasons behind such presentations were seasonal availability and spoilage during storage of the plant-derived succulent bio-materials.

Now, the time has come to stop the unhealthy practices of the addition of harmful chemicals as well as to stop the wastage of important phytochemicals inside the herbal medicines.

At the present stage of civilization, the ancient problems of storage and transportation of succulent bio-materials are not at all relevant. So, we do not need the addition of any synthetic chemical to overcome the ancient problems. We are also not forced to use only the dry plant parts or their chemical extracted portions to overcome the old problems, as we are having much more efficient alternatives [7].

As per the present concept, chemical/ synthetic preservatives should not get any chance of incorporation in the proposed succulent bio-medicines. As these medicines are to be encapsulated and transported through the cold chain, the chance of multiplication of microorganisms (if present) will be very less. However, if any such requirement is felt, only preservatives of natural origin may be considered for use.

\subsubsection{The Bio-preservatives}

Several bio-preservatives are identified by many scientists, but their efficacies are to be tested in the preservation of succulent bio-medicines or bio-materials.

Essential oils of Onion, Clove, Garlic, Cinnamon, Coriander, Mount Atlas mastic, Mint Thyme, Zizyphus jujuba, Artemisia anomala, Ginger oil and Callistemon lanceolatus are advocated by Miguel et al. as bio preservatives [242]. Essential oils of Basil, Oregano, Rosemary, Sage, Thyme, Coriander, Allspice, Cinnamon, Clove, Mustard, Nutmeg, Vanilla, Bergamot, Eucalyptus, and Lemon are listed as biopreservative by Ebrahami et al. [243]. But detailed descriptions of various herbs, herb compounds, spices, essential oils of plants, natural substances, animal, bird and insect origin products, etc. are described and discussed in one recent book [7].

The concentrated juice or the essential oil derived from the same medicinal plant of original succulent bio-medicine may be the best choice (as the essential oil of Azadirachta indica leaves may be used to cover the frozen Azadirachta indica leaf juice or pulp for preservation, if it can perform the function). These may play the role of covering bio-preservative of the succulent bio-medicines most efficiently (Figs. 2 and $\mathbf{3}$ ). The next preference may be given to honey and then other biopreservatives.

\subsubsection{Encapsulation of the Biomedicines}

\subsubsection{Encapsulating Materials of Biological Origin}

Many materials of biological origin may be considered for their efficacy of encapsulation. Like the bio-preservatives, their efficacy in the present purpose is to be tested. Among the plant-derived materials, plant exudates (Gum Arabic, Gum karaya, Mesquite gum); plant extracts (Galactomannans, Soluble soybean, Pectin, Cocoa butter); different Starch and 
Cellulose derivatives, Polysaccharides; proteins like Gluten (corn), Wheat gluten, isolates of Pea or Soy; lipids like Fatty acids/ alcohols, Glycerides, Waxes (Bee wax, Candelilla wax, Carnauba wax), Shellac resin, Phospholipids are important. Among the marine origin products, Carrageenan, Alginate; animal or microbial products like Xanthan, Gellan, Dextran, Chitosan (carbohydrate), Caseins, Collagen, Corn, Whey proteins, Gelatin (protein), etc. are important [242, 244].

Different coating techniques, their qualities, and limitations as well as various coating materials of each group require detailed analysis before finalization [7].

At the initial stage of research, collagen or a combination of collagen and cellulose (as used in a sausage casing) and soft gel capsular materials may be considered for use.

\subsubsection{Models for Encapsulation of Succulent Bio- Medicines}

The succulent bio-medicines may be encapsulated in different forms. A few models are prepared for that purpose. These are displayed in Figs. (4-6).

\subsubsection{Important Relevant Areas Need Consideration during Finalization of the Whole Process}

The type 1 encapsulation procedure (Fig. 4) can be applied where no bio-preservative is used. The succulent bio-medicines may be directly encapsulated to enter in the next step. The powder of the seed/ dry fruits etc. maybe directly encapsulated following that procedure.

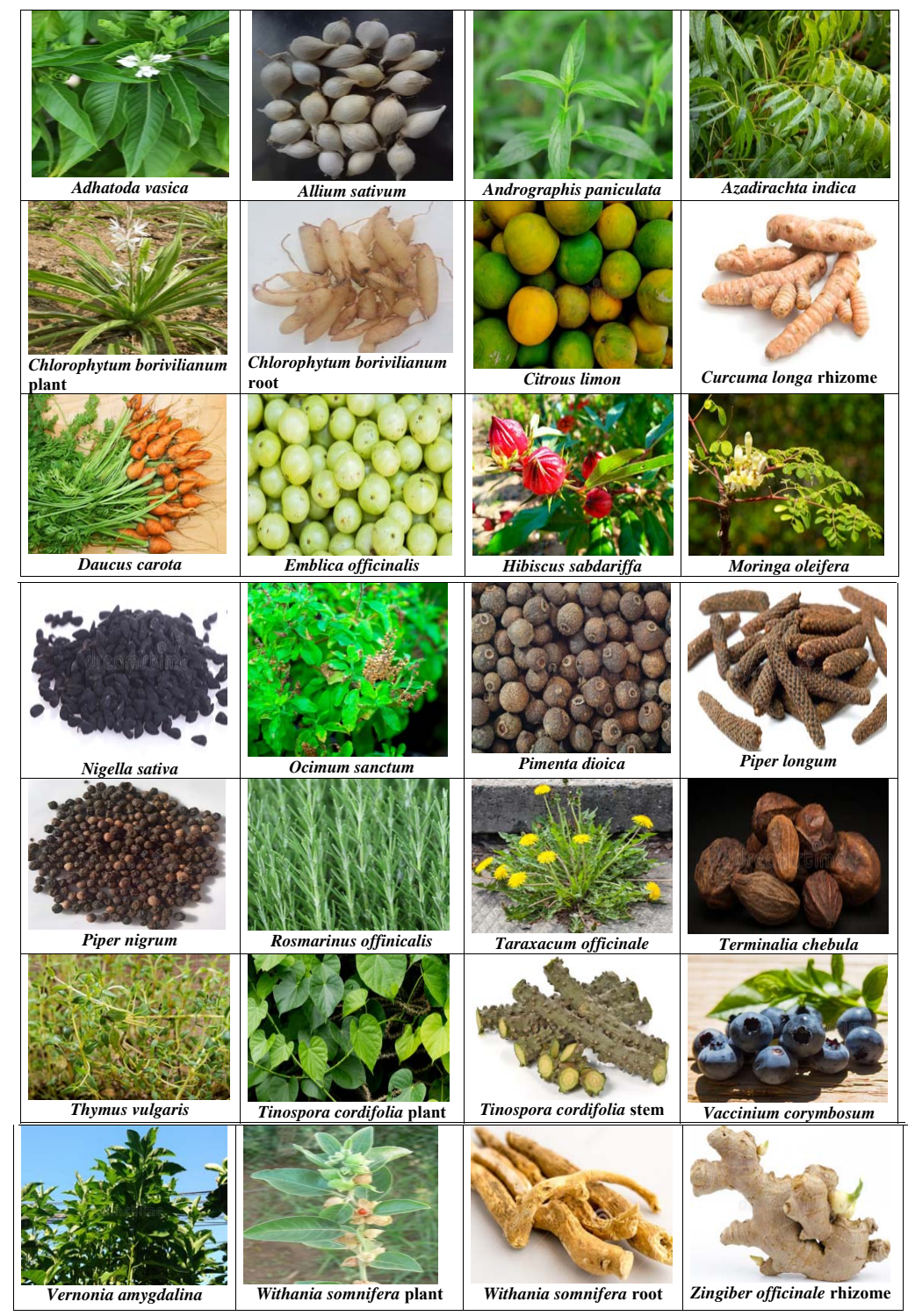

Fig. (1). Plants selected for preparation of anti-COVID-19 biomedicines.

*Photographs are taken mainly from the stock photos available royalty-free from https://www.dreamstime.com/photos-images/adhatoda.html 


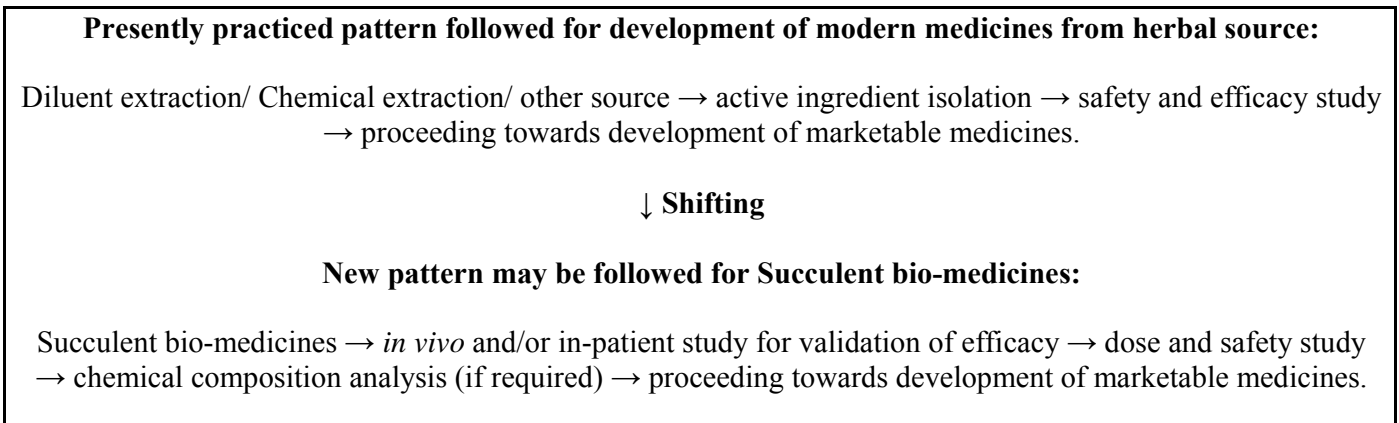

Fig. (2). Development of succulent biomedicines from the herbal source.

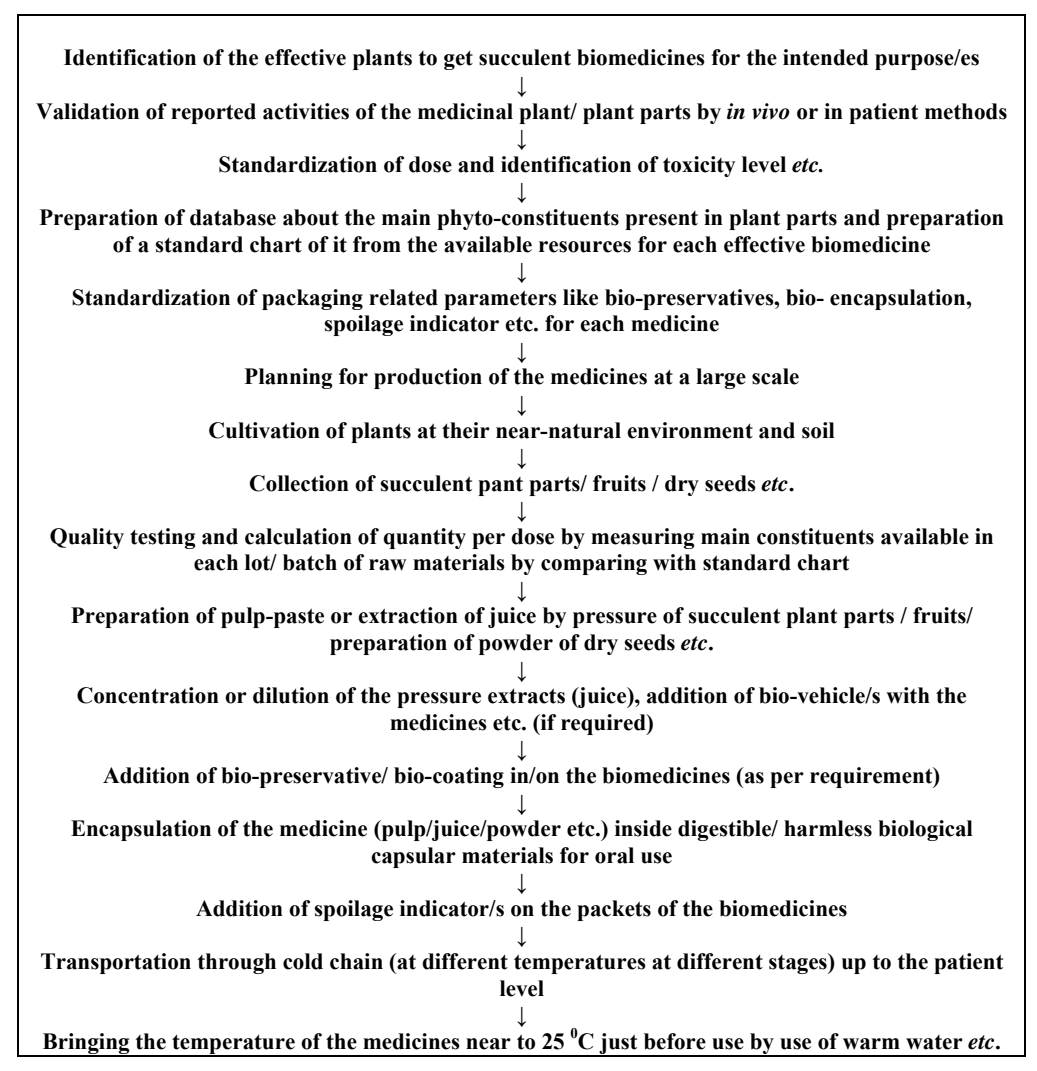

Fig. (3). Flow chart of preparation and transport of proposed succulent biomedicines for control of COVID-19.

The bio-preservatives may be mixed with the biomedicines before encapsulation following the model of type 2 (Fig. 5).

For encapsulation of the succulent bio-medicines by type 3 process, some other points are to be considered (Fig. 6).

(a) Pulp of succulent medicines or their juices may be the innermost part. That part may be made frozen before entering the next step.

(b) The previously collected juice of the same plant part of bio-medicine may be used directly or in concentrated form as the covering bio-preservative as a preferred option, if it can serve the purpose. The essential oil of the same plant part may also be used. (c) Honey, essential oils of other plant sources, or concentrated sugary sap of some other plants may also be used as a covering preservative.

\subsubsection{Set-up for Preparation of Bio-medicines for Packaging and Transportation}

A model set up for the preparation of succulent biomedicines before packaging by stepwise freezing. Modification of this model or use of other similar setups may be performed as per the requirement.

\subsubsection{Packaging of Biomedicines}

The individual doses of the succulent encapsulated biomedicines may be packed singly inside small chambers of a 
tray or box. The tray or box should be tolerable to deep freezing and should have no toxic effect on the biomedicines kept inside them [as steel/glass etc.]. However, some tricks like the use of a bio-lubricator may be adopted for better safety of the biomedicines from the adherence with the materials of the packing box (Fig. 7).

\subsubsection{Storage and Transportation of the Biomedicines}

For storage and transportation of succulent biomedicines, introduction of a novel system is required to serve the required purposes. This can be developed by logical use of the available technologies to fulfill the requirements.

\subsubsection{A Novel Freezing System for Storage of Succulent Bio- medicines and other Succulent Bio-Products}

In order to achieve extended storage life, the succulent biomedicines may be kept below $-23^{\circ} \mathrm{C}$, as per available study reports [245].

So, after production, all of the bio-medicines may be stored at some effective low temperature, maybe at $-25^{\circ} \mathrm{C}$ at deep freezers. During transportation to the wholesalers from the factory or during storage by the wholesalers, it may be performed at the same temperature $\left(-25^{\circ} \mathrm{C}\right)$. But the retail shops have to sell the products. They may be equipped with a freezing system with some special facilities as shown in Fig. (8).

The retail shopkeepers may store the bio-medicines for a longer period at the bottom chamber. The middle chamber 1 may be used as per the requirement and schedule for the sale of the medicines. The middle chamber 2 may store the medicines for a few hours.

The top chamber may be used to keep the medicines/ other succulent bioproducts for a while before delivering them directly to the consumers. This model needs detailed study before finalization.

All the above three chambers are for the storage of the medicines for a little time as per their requirement and necessity. The three upper chambers may be gradually of reduced size than the bottom chamber as per the requirements.

\subsubsection{Use of Spoilage Indicator/s on the Packets of Succulent Biomedicines}

The succulent bio-medicines are vulnerable to easy spoilage. The reason maybe aging, the gap in the cold chain, sabotage or there may be other previously unpredictable reason/s. There should be one easy detection procedure for the consumer/ end-user to identify the condition of the inner medicines/ products without opening the packets.

Among the available study reports on that subject, change of color of some added chemicals on the packet due to exposure of the packed materials to any environment other than the scheduled one may be considered as most important.

Electronic time-temperature indicator (eTTI) and Vaccine Vial Monitors (VVM) are two important systems to perform the work. Though the eTTI monitors can detect essentially all cold-chain breaks and can detect some other issues [246], but the VVM system may be preferred due to reasons like easy use, low cost, etc.

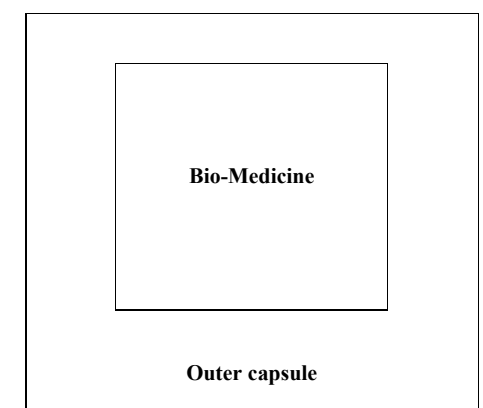

Fig. (4). Type 1 process of succulent biomedicine encapsulation. (Bio-Medicine covered by bio-capsule).

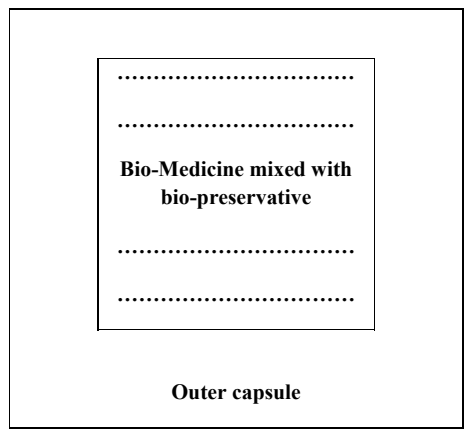

Fig. (5). Type 2 process of succulent biomedicine encapsulation (Bio-medicine mixed with bio-preservative and covered by bio-capsule). 


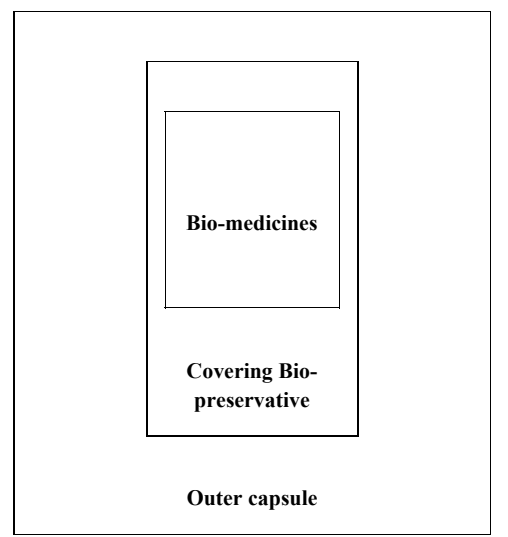

Fig. (6). Type 3 process of succulent biomedicine encapsulation. (Bio-medicine coated with bio-preservative and covered by bio-capsule).

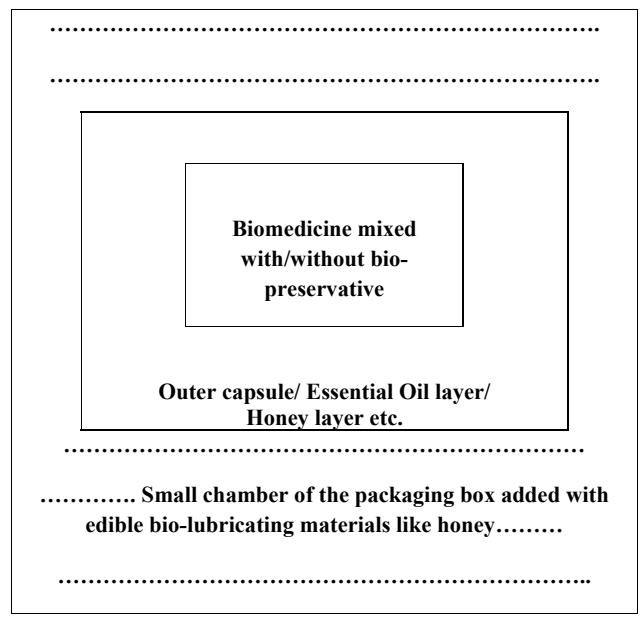

Fig. (7). A sample packaging technique for succulent biomedicines.

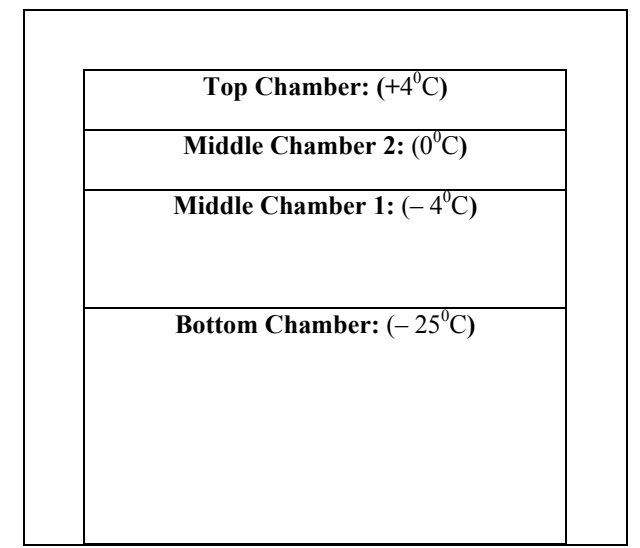

Fig. (8). A sample design of storage arrangement of succulent biomedicines (design of freezing chambers with different temperatures to stock succulent biomedicines).

In the VVM system, some temperature-sensitive chemical colors are used on the packets. After exposure to a certain temperature/s for a certain period of time, the color of these chemicals' changes. Color identity is kept surrounding these chemicals. Observing the color of the surrounding area and comparing it with the color of the middle chemicals, anybody can understand the actual condition of the products kept inside the packets [7].

Such coloring materials are commonly used to determine the actual condition of the thermolabile vaccines. As these chemicals are generally used in the field of storage and transportation of vaccines, these are termed as Vaccine Vial Monitors. 


Succulent bio-medicines
$\downarrow$
Made frozen in the first chamber (Type 1)
OR
OR
Mixed with bio-preservative of same/ other origin and made frozen in the first chamber (Type 2)
Made frozen in the first chamber and then covered with bio-preservative keeping the material at
suspended condition or by spraying the bio-preservative to cover it equally from each side and
again made frozen (Type 3)
$\downarrow$
The material can be kept inside outer bio-capsule
$\downarrow$
Made frozen in the next chamber
$\downarrow$
Proceed towards packaging, sealing etc. before storage

Fig. (9). Preparation of succulent biomedicines for transportation.

\subsubsection{Vaccine Vial Monitors}

A Vaccine Vial Monitor (VVM) is a label containing a heat-sensitive material which is placed on a vaccine vial to register cumulative heat exposure over time. The combined effects of time and temperature cause the inner square of the VVM to darken, gradually and irreversibly. A direct relationship exists between the rate of color change and temperature [247].

Vaccine vial monitors are used generally to warn health care workers if a vaccine was damaged by heat. The darkened color of the monitor chemical indicates that the vaccine is no longer effective and should not be used [248].

\subsubsection{Chemicals used in Vaccine Vial Monitors}

In 1979, the World Health Organization (W.H.O.) conceived the concept of Vaccine Vial Monitor, where ptoluene sulfonate was used as the chemical for the purpose. Research, trial, and discussion were going on and in 1988, a new type of chemical, di-acetylene polymers came into the field with a better performance [249]. But the actual chemicals used presently in VVMs are not available in literature.

\subsubsection{Reaction Rate of Vaccine Vial Monitors}

From the available literature, one chart of the reaction rate of some Vaccine Vial Monitors as per their heat-stability is available. It is shown in Table $\mathbf{1}$ [250].

Table 1. Reported vaccine vial monitors for identification of spoilage.

\begin{tabular}{|c|c|c|c|}
\hline Category & $\begin{array}{l}\text { No. of days } \\
\text { to end point } \\
\text { at } 37^{\circ} \mathrm{C}\end{array}$ & $\begin{array}{l}\text { No. of days to } \\
\text { end } \\
\text { point at } 25^{\circ} \mathrm{C}\end{array}$ & $\begin{array}{r}\text { Time to end } \\
\text { point at } 5^{\circ} \mathrm{C}\end{array}$ \\
\hline $\begin{array}{c}\text { VVM } 30 \\
\text { (High stability) }\end{array}$ & 30 & 193 & $\begin{array}{l}\text { More than } 4 \\
\text { Years }\end{array}$ \\
\hline $\begin{array}{c}\text { VVM } 14 \\
\text { (Medium stability) }\end{array}$ & 14 & 90 & $\begin{array}{c}\text { More than } 3 \\
\text { Years }\end{array}$ \\
\hline $\begin{array}{c}\text { VVM } 7 \\
\text { (Moderate stability) }\end{array}$ & 07 & 45 & $\begin{array}{c}\text { More than } 2 \\
\text { Years }\end{array}$ \\
\hline $\begin{array}{c}\text { VVM } 2 \\
\text { (Least stability) }\end{array}$ & 02 & Not Available & 225 days \\
\hline
\end{tabular}

\subsubsection{Use of Succulent Bio-medicines by the Patients}

For storage of succulent bio-medicines, the health centres, hospitals, clinics, or dispensaries may be equipped with the special designed freezers (Fig. 8). But for storage of these medicines by the consumers/patients, the recommendation of the researchers is required separately for each medicine.

It is expected that the encapsulated powdered biomedicines may tolerate to some extent higher temperatures during storage and transportation than the juices or pulps (Fig. 9). This section may also be framed as per the research results.

But in all cases, it may be the best option to swallow the capsules of succulent bio-medicines after increasing their temperature near $25^{\circ} \mathrm{C}$. The use of lukewarm water may be an option to achieve that temperature.

\subsection{Requirement of Special Legislative Control on Preparation and Marketing of Succulent Bio-medicines and other alike Bio-products}

All the succulent bio-medicines and other alike bioproducts are prone to lose their efficacy or even conversion to some toxic materials if proper quality control measures are not taken during the preparation of the products and if any gap in the maintenance of proper cold chain arises during the longways of transportation and storage. As a part of the business competition or any other bad intentions, the medicines may be added with some toxic chemicals, some slow poisoning materials, or maybe adulterated with some health hazardous chemicals during production or in the way of their journey towards consumers.

There may be related many other problems. Compromise with the quality of biomedicines is among them.

For example - to keep production and marketing costs at a very low level to market the products at a very low cost, there may be a different compromises with the desired or directed measures by some manufacturers.

The two convenient malpractices may be the use of lowgrade raw materials (without an appropriate level of phytoconstituents or the wrong plant part) and the intentional break in the cold chain.

So, many low-grade biomedicines may be sold in the market without following strict measures of manufacturing, transport, and storage of the products which may ultimately jeopardize the whole system!

To prevent all such malpractices, there should be some 
strong legislative control on production, transportation, storage, and marketing of these bio-medicines. As the proposed medicines are of a novel type, so the previously formulated rules and regulations may not cover all the related aspects. Specific guidelines should be imposed from the end of the competent authorities before giving any permission to manufacture and marketing of such products [7].

\section{CONCLUSION}

In conclusion, the following points may be chalked out.

(1) The succulent biomedicines can act as preventive medicine for COVID 19.

(2) These also can work as medicines for the reduction of severity of disease symptoms of COVID-19.

(3) Thus the technique of immune-modulation through dilatory intake of succulent bio-medicines may be a key tool to control many other dangerous diseases and also can act to prevent any future epidemics/pandemics.

(4) The new concept can act as the basis to lead research for the development of alike procedures for prevention, control, and treatment of many other diseases of infective as well as non-infective origin.

(5) Different Bio-healthcare products may be prepared solely by different succulent parts of plants for their effective use throughout the globe in all seasons following the same procedures.

(6) Preservative and all other added chemical-free fruit pulp and fruit juices and many other food/ food products can be produced with least or zero processing and can be transported to the global consumers after adding some modifications with the basic system described.

(7) Cultivation of Medicinal plants for the production of biomedicines and their export throughout the world can involve a huge number of rural unemployed persons of the countries having plant resources. On the other hand, there are ample chances to perform agri-business through the development of a new type of agriculture and horticulture-related industries.

\section{ETHICS APPROVAL AND CONSENT TO PARTI- CIPATE}

Not applicable.

\section{HUMAN AND ANIMAL RIGHTS}

Not applicable.

\section{CONSENT FOR PUBLICATION}

Not applicable.

\section{AVAILABILITY OF DATA AND MATERIALS}

Not applicable.

\section{FUNDING}

None.

\section{CONFLICT OF INTEREST}

The author confirms that this article content has no conflict of interest.

\section{ACKNOWLEDGEMENTS}

Declared none.

\section{REFERENCES}

[1] Ahmadivand A, Gerislioglu B, Ramezani Z, Kaushik A, Manickam P, Ghoreishi SA. Functionalized terahertz plasmonic metasensors: Femtomolar-level detection of SARS-CoV-2 spike proteins. Biosens Bioelectron 2021; 177(112971)112971

[http://dx.doi.org/10.1016/j.bios.2021.112971] [PMID: 33434777]

[2] Kevadiya BD, Machhi J, Herskovitz J, et al. Diagnostics for SARSCoV-2 infections. Nat Mater 2021; 20(5): 593-605. [http://dx.doi.org/10.1038/s41563-020-00906-z] [PMID: 33589798]

[3] WHO living guideline: Drugs to prevent COVID-19. 2021. Available from:

https://apps.who.int/iris/bitstream/handle/10665/339877/WHO-2019-n CoV-prophylaxes-2021.1-eng.pdf

[4] Pattanayak S, Mandal TK, Bandyopadhyay SK. Validation and therapeutic use of succulent plant parts - opening of a new horizon of alternative medicine. Explor Anim Med Res 2016; 6(1): 08-14.

[5] Pattanayak S. Healthcare system using succulent parts of plants, Volume I: For infectious diseases. 2019. ISBN: 978-93-5346-842-2

[6] Pattanayak S. Processed foods - are they safe? Explor Anim Med Res 2017; 7(2): 125-31.

[7] Pattanayak S. Healthcare system using succulent parts of plants, Volume 2: Steps for production and marketing of some selected healthcare products. 2019. ISBN: 978-93-5391-625-1

[8] Mandal TK, Pattanayak S. Dietary modulation with fatty acids: a potential way to overcome COVID-19. Explor Anim Med Res 2020; 10(2): 97-9.

[9] Pattanayak S. Succulent biomedicines - an effective way of getting protection against diseases through immunomodulation. Explor Anim Med Res 2020; 10(2): 112-23.

[10] Pattanayak S. Use of succulent bio-medicines to control COVID-19. 2020. ISBN: 978-93-5407-265-9

[11] Sun AY, Wang Q, Simonyi A, Sun GY. Botanical phenolics and neurodegeneration. Herbal medicine: Biomolecular and clinical aspects. $2^{\text {nd }}$ edn. Taylor \& Francis Group, Boca Raton, FL : CRC Press 2011; pp. 33487-2742.

[http://dx.doi.org/10.1201/b10787-16]

[12] Paur I, Carlsen MH, Halvorsen BL, Blomhoff R. Antioxidants in herbs and spices: roles in oxidative stress and redox signalling. In: Herbal medicine: biomolecular and clinical aspects. $2^{\text {nd }}$ edition. Taylor \& Francis Group, Boca Raton, F: CRC Press 2011. [http://dx.doi.org/10.1201/b10787-3]

[13] Packer L, Cadenas E. Oxidative stress and disease. In: Herbal medicine: biomolecular and clinical aspects. 2nd. edition. Benzie IFF, Wachtel-Galor S. Taylor \& Francis Group, Boca Raton, FL: CRC Press 2011.

[14] Cundell DR. Herbal phytochemicals as immunomodulators. Curr Immunol Rev 2014; 10(2): 1-19. [Bentham Science Publishers.]. [http://dx.doi.org/10.2174/1573395510666140915213156]

[15] Kumar D, Arya V, Kaur R, Bhat ZA, Gupta VK, Kumar V. A review of immunomodulators in the Indian traditional health care system. J Microbiol Immunol Infect 2012; 45(3): 165-84

[http://dx.doi.org/10.1016/j.jmii.2011.09.030] [PMID: 22154993]

[16] Shahbazi S, Bolhassani A. Immunostimulants: types and functions. J Med Microbiol Infec Dis 2016; 4(3-4): 45-51.

[17] Huang CF, Lin SS, Liao PH, Young SC, Yang CC. The immunopharmaceutical effects and mechanisms of herb medicine. Cell Mol Immunol 2008; 5(1): 23-31.

[http://dx.doi.org/10.1038/cmi.2008.3] [PMID: 18318991]

[18] Patel K. A review on herbal immunoadjuvant. Int J Pharm Life Sci 2012; 3(3): 1568-76.

[19] Roshan N, Savitri P. Review on chemical constituents and parts of plants as immunomodulators. Res J Pharm Biol Chem Sci 2013; 4(1): 76-89.

[20] Peng C, Wang X, Chen J, Jiao R, Wang L, et al. Biology of ageing and role of dietary antioxidants. BioMed Res Intern 2014; (831841): 01-13. 
[http://dx.doi.org/10.1155/2014/831841]

[21] Pattanayak S, Mandal TK, Bandyopadhyay SK. Ethnomedicinal study of plants used for protection and stimulation of liver in southern West Bengal, India. Explor Anim Med Res 2016; 6(2): 164-78. b

[22] Mukhopadhyay MK, Banerjee P, Nath D. Phytochemicals biomolecules for prevention and treatment of human diseases - a review. Intern J Scientific Engineering Res 2012; 3(7): 1-32.

[23] Pattanayak S. Alternative to antibiotics from herbal origin - outline of a comprehensive research project. Curr Pharmacogenomics Person Med 2018; 16: 9-62.

[http://dx.doi.org/10.2174/1875692116666180419154033]

[24] Rao KVB, Munjal M, Patnayak A, Karthik L, Kumar G. Phytochemical composition, antioxidant, antimicrobial and cytotoxic potential of methanolic extracts of Adhatoda vasica (Acanthaceae). Res J Pharm Tech 2013; 6(9): 997-1002.

[25] Pant M, Basu S, Sindhu RK. Rachana. Antioxidant and free radical scavenging potential of ethanolic fraction of Adhatoda vasica in A 549 cell line. Asian J Pharm Clin Res 2015; 8(6): 244-9.

[26] Singh SK, Patel JR, Dangi A, Bachle D, Kataria RK. A complete over review on Adhatoda vasica a traditional medicinal plant. J Medic Plants Studies 2017; 5(1): 175-80.

[27] Jinyvarghese K, Karpe ST. Immunostimulant activity of Adhatoda vasica, Lawsonia inermis and Alkanna tinctoria. Indian Drugs 2005; 42(6): 345-52.

[28] Vinothapooshan G, Sundar K. Immunomodulatory activity of various extracts of Adhatoda vasica Linn. in experimental rats. Afr J Pharm Pharmacol 2011; 5(3): 306-10 [http://dx.doi.org/10.5897/AJPP10.126]

[29] Chavan R, Gohil D, Shah V, Kothari S, Chowdhary A. Anti-viral activity of Indian medicinal plant Justicia adhatoda against Herpes simplex virus: an in-vitro study. Int J Pharm Bio Sci 2013; 4(4): 769-78.

[30] Chavan R, Chowdhary A. In vitro inhibitory activity of Justicia adhatoda extracts against Influenza virus infection and hemagglutination. Int J Pharm Sci Rev Res 2014; 25(2): 231-6.

[31] Dhankhar S, Kaur R, Ruhil S, Balhara M, Dhankhar S, Chhillar AK. A review on Justicia adhatoda: a potential source of natural medicine. Afr J Plant Sci 2011; 5(11): 620-7.

[32] Alam K, Pathak D, Ansari SH. Phytochemical and pharmacological investigations on Adhatoda zeylanica (Medic.): a review. Phog J 2010; 2(12): 513-9.

[http://dx.doi.org/10.1016/S0975-3575(10)80041-0]

[33] Capasso A. Antioxidant action and therapeutic efficacy of Allium sativum L. Molecules 2013; 18(1): 690-700. [http://dx.doi.org/10.3390/molecules18010690] [PMID: 23292331]

[34] Awan KA, Butt MS, Haq IU, Suleria HAR. Investigating the antioxidant potential of garlic (Allium sativum) extracts through different extraction modes. Curr Bioact Compd 2018; 14: 1-6. [http://dx.doi.org/10.2174/1573407213666171024121712]

[35] Shang A, Cao SY, Xu XY, et al. Bioactive compounds and biological functions of garlic (Allium sativum L.). Foods 2019; 8(7): 1-31. [http://dx.doi.org/10.3390/foods8070246] [PMID: 31284512]

[36] Harris JC, Cottrell SL, Plummer S, Lloyd D. Antimicrobial properties of Allium sativum (garlic). Appl Microbiol Biotechnol 2001; 57(3): 282-6.

[http://dx.doi.org/10.1007/s002530100722] [PMID: 11759674]

[37] Arreola R, Quintero-Fabián S, López-Roa RI, Flores-Gutiérrez EO, Reyes-Grajeda $\mathrm{J}$, et al. Immunomodulation and anti-inflammatory effects of garlic compounds. J Immunology Res 2015; 401630: 01-13.

[38] Moutia M, Habti N, Badou A. In vitro and in vivo immunomodulator activities of Allium sativum L. Evid Based Complement Alternat Med 2018; 20184984659

[http://dx.doi.org/10.1155/2018/4984659] [PMID: 30008785]

[39] Riggs DR, DeHaven JI, Lamm DL. Allium sativum (garlic) treatment for murine transitional cell carcinoma. Cancer 1997; 79(10): 1987-94. [http://dx.doi.org/10.1002/(SICI)1097-0142(19970515)79:10<1987::A ID-CNCR21>3.0.CO;2-Q] [PMID: 9149027]

[40] Mehrbod P, Amini E, Tavassoti-Kheiri M. Antiviral activity of garlic extract on Influenza virus. Iran J Virol 2009; 3(1): 19-23.

[http://dx.doi.org/10.21859/isv.3.1.19]

[41] Harazem R, Rahman SAE, Kenawy AE. Evaluation of antiviral activity of Allium cepa and Allium sativum extracts against Newcastle disease virus. Alex J Vet Sci 2019; 61(1): 108-18.

[http://dx.doi.org/10.5455/ajvs.29663]

[42] Ambasta SP. The useful plants of India. New Delhi, India: National Institute Science Communication and Information Resources. CSIR 1986.
[43] Prakash ELS, Ali KSH, Divya N. VijayaRani RK, Manavalan R. Evaluation of in-vitro antioxidant activity of leaf extract of Andrographis paniculata. Res J Pharm Biol Chem Sci 2011; 2(2): 891-7.

[44] Jayakumar T, Hsieh CY, Lee JJ, Sheu JR. Experimental and clinica pharmacology of Andrographis paniculata and its major bioactive phytoconstituent Andrographolide. Evid Based Complement Alternat Med 2013; 2013846740

[http://dx.doi.org/10.1155/2013/846740] [PMID: 23634174]

[45] Sundaramoorthy S, Rastogi A, Sathiavelu M, Arunachalam S. A detailed analysis of the antioxidant activity of the medicinal plant Andrographis paniculata. Int J Drug Dev Res 2014; 6(1): 231-8.

[46] Wang W, Wang J, Dong SF, et al. Immunomodulatory activity of andrographolide on macrophage activation and specific antibody response. Acta Pharmacol Sin 2010; 31(2): 191-201. [http://dx.doi.org/10.1038/aps.2009.205] [PMID: 20139902]

[47] Churiyah, Pongtuluran OB, Elrade Rofaani E, Tarwadi. Antiviral and immunostimulant activities of Andrographis paniculata. Hayati J Biosci 2015; 22(2): 67-72.

[http://dx.doi.org/10.4308/hjb.22.2.67]

[48] Gupta S, Mishra KP, Ganju L. Broad-spectrum antiviral properties of Andrographolide. Arch Virol 2016; 1-16.

[http://dx.doi.org/10.1007/s00705-016-3166-3] [PMID: 27896563]

[49] Wintachai P, Kaur P, Lee RCH, et al. Activity of andrographolide against chikungunya virus infection. Sci Rep 2015; 5(14179): 14179. [http://dx.doi.org/10.1038/srep14179] [PMID: 26384169]

[50] Ali-Seyed M, Vijayaraghavan K. Dengue virus infections and antidengue virus activities of Andrographis paniculata. Asian Pac J Trop Med 2020; 13(2): 49-55.

[http://dx.doi.org/10.4103/1995-7645.275412]

[51] Balaji TK, Kulal Shivaji R, Rangar Krishna K, Kokare Balasaheb N. Medicinal uses of neem (Azadirachta indica) in human life: a review. Int J Life Sci 2018; A10(Special Issue): 181-4.

52] Dhakal S, Aryal P, Aryal S, Bashyal D, Khadka D. Phytochemical and antioxidant studies of methanol and chloroform extract from leaves of Azadirachta indica A. Juss. in tropical region of Nepal. J Pharmacogn Phytother 2016; 8(12): 203-8.

[http://dx.doi.org/10.5897/JPP2016.0425]

[53] Pokhrel B, Rijal S, Raut S, Pandeya A. Investigations of antioxidant and antibacterial activity of leaf extracts of Azadirachta indica. Afr J Biotechnol 2015; 14(46): 3159-63

[http://dx.doi.org/10.5897/AJB2015.14811]

[54] Mandal-Ghosh I, Chattopadhyay U, Baral R. Neem leaf preparation enhances Th1 type immune response and anti-tumor immunity against breast tumor associated antigen. Cancer Immun 2007; 7(8): 8. [PMID: 17394284]

[55] Chouhan G, Islamuddin M, Want MY, et al. Apoptosis mediated leishmanicidal activity of Azadirachta indica bioactive fractions is accompanied by Th1 immunostimulatory potential and therapeutic cure in vivo. Parasit Vectors 2015; 8: 183 [http://dx.doi.org/10.1186/s13071-015-0788-3] [PMID: 25884649]

[56] Bharitkar YP, Bathini S, Ojha D, et al. Antibacterial and antiviral evaluation of sulfonoquinovosyldiacylglyceride: a glycolipid isolated from Azadirachta indica leaves. Lett Appl Microbiol 2014; 58(2): 184-9.

[http://dx.doi.org/10.1111/lam.12174] [PMID: 24118020]

[57] Imrana I, Altafb I, Ashrafa M, Javeeda A, Munirc N, et al. In vitro evaluation of antiviral activity of leaf extracts of Azadirachta indica, Moringa oleifera, and Morus alba against the foot and mouth disease virus on BHK-21 cell line. Sci Asia 2016; 42: 392-6.

[http://dx.doi.org/10.2306/scienceasia1513-1874.2016.42.392]

[58] Deore SL, Khadabadi S. Antiinflammatory and antioxidant activity of Chlorophytum borivilianum root extracts. Asian J Chem 2008; 20(2): 983-6.

[59] Ashraf MF, Abd Aziz M, Stanslas J, Ismail I, Abdul Kadir M. Assessment of antioxidant and cytotoxicity activities of saponin and crude extracts of Chlorophytum borivilianum. ScientificWorldJournal $2013 ; 2013216894$ [http://dx.doi.org/10.1155/2013/216894] [PMID: 24223502]

[60] Sharma P, Chandrul KK. Chlorophytum borivilianum (Safed musli): a vital herbal drug. Int J Pharm Med Res 2017; 5(1): 401-11.

[61] Thakur GS, Bag M, Sanodiya BS, et al. Chlorophytum borivilianum: a white gold for biopharmaceuticals and neutraceuticals. Curr Pharm Biotechnol 2009; 10(7): 650-66.

[http://dx.doi.org/10.2174/138920109789542084] [PMID: 19751181]

[62] Thakur M, Connellan P, Deseo MA, Morris C, Dixit VK. Immunomodulatory polysaccharide from Chlorophytum borivilianum 
roots. Evid Based Complement Alternat Med 2011; 2011598521 [http://dx.doi.org/10.1093/ecam/neq012] [PMID: 21792363]

[63] Singh D, Pokhriyal B, Joshi YM, Kadam V. Phytopharmacological aspects of Chlorophytum borivilianum (Safed musli): A review. Int J Res Pharm Chem 2012; 2(3): 853-9.

[64] Singh B, Yadav SK. Antiviral and cytokine modulating potential of Chlorophytum borivilianum hot aqueous extract. $16^{\text {th }}$ ICID Abstracts. Int J Infect Dis 2014; 21S: 1-460.

[http://dx.doi.org/10.1016/j.ijid.2014.03.1358]

[65] Rekha C, Poornima G, Manasa M, Abhipsa V, Pavithradevi J, et al. Ascorbic acid, total phenol content and antioxidant activity of fresh juices of four ripe and unripe citrus fruits. Chem Sci Trans 2012; 1(2): 303-10.

[http://dx.doi.org/10.7598/cst2012.182]

[66] Klimek-Szczykutowicz M, Szopa A, Ekiert H. Citrus limon (Lemon) phenomenon- a review of the chemistry, pharmacological properties, applications in the modern pharmaceutical, food, and cosmetics industries, and biotechnological studies. Plants 2020; 9(1): 119. [http://dx.doi.org/10.3390/plants9010119] [PMID: 31963590]

[67] Kumari S, Sarmah N, Handique AK. Antioxidant and antimicrobial potential of ripen and unripe juice of Citrus limon. Int J Pharm Sci Invent 2014; 3(6): 18-20.

[68] Liu Y, Bi W. Research progress of nutritional components and comprehensive utilization of Citrus limon. J Neijiang Normal University $2012 ;$ p. 8

[69] Hindi NKK, Chabuck ZAG. Antimicrobial activity of different aqueous lemon extracts. J Appl Pharm Sci 2013; 3(06): 74-8. [http://dx.doi.org/10.7324/JAPS.2013.3611]

[70] Diab KAE. In vitro studies on phytochemical content, antioxidant, anticancer, immunomodulatory, and antigenotoxic activities of lemon, grapefruit, and mandarin citrus peels. Asian Pac J Cancer Prev 2016; 17(7): 3559-67. [PMID: 27510009]

[71] Gharagozloo M, Ghaderi A. Immunomodulatory effect of concentrated lime juice extract on activated human mononuclear cells. J Ethnopharmacol 2001; 77(1): 85-90.

[http://dx.doi.org/10.1016/S0378-8741(01)00269-0] [PMID: 11483382]

[72] Chaturvedi D, Shrivastava R, Raj SN. Basketful benefit of Citrus limon. Int Res J Pharm 2016; 7(6): 1-5.

[http://dx.doi.org/10.7897/2230-8407.07653]

[73] Jaiswal SK, Gupta VK, Siddiqi NJ, Pandey RS, Sharma B. Hepatoprotective effect of Citrus limon fruit extract against carbofuran induced toxicity in Wistar rats. Zhongguo Shengwuzhipinxue Zazhi 2015; 686071: 1-10.

[http://dx.doi.org/10.1155/2015/686071]

[74] Loizzo MR, Sicari V, Tundis R, Leporini M, Falco T, Calabrò V. The influence of ultrafiltration of Citrus limon L. Burm. cv FC juice on its chemical composition and antioxidant and hypoglycemic properties. Antioxidants 2019; 8(1): 23

[http://dx.doi.org/10.3390/antiox8010023] [PMID: 30654432]

[75] Tanvir EM, Hossen S, Hossain F, Afroz R, Gan SH, et al. Antioxidant properties of popular turmeric (Curcuma longa) varieties from Bangladesh. J Food Qual 2017; 8471785: 1-8.

[http://dx.doi.org/10.1155/2017/8471785]

[76] Mošovská S, Petáková P, Kaliňák M, Mikulajová A. Antioxidant properties of curcuminoids isolated from Curcuma longa L. Acta Chim Slov 2016; 9(2): 130-5.

[http://dx.doi.org/10.1515/acs-2016-0022]

[77] Omosa LK, Midiwo JO, Kuete V. Medicinal spices and vegetables from Africa - therapeutic potential against metabolic, inflammatory, and Systemic diseases, Chapter 19 - Curcuma longa. In: Academic Press. 2017; pp. 425-35.

[http://dx.doi.org/10.1016/B978-0-12-809286-6.00019-4]

[78] Srivastava RM, Singh S, Dubey SK, Misra K, Khar A. Immunomodulatory and therapeutic activity of curcumin. Int Immunopharmacol 2011; 11(3): 331-41.

[http://dx.doi.org/10.1016/j.intimp.2010.08.014] [PMID: 20828642]

[79] Alambra JR, Russel R, Alenton RR, Gulpeo PCR, Mecenas CL, et al. Immunomodulatory effects of turmeric, Curcuma longa (Magnoliophyta, Zingiberaceae) on Macrobrachium rosenbergii (Crustacea, Palaemonidae) against Vibrio alginolyticus (Proteobacteria, Vibrionaceae). Intern J Bioflux Soc 2012; 5(1): 13-7.

[80] Tawwab AM, Abbass FE. Turmeric powder, Curcuma longa L., in common carp, Cyprinus carpio L., diets: Growth performance, innate immunity, and challenge against pathogenic Aeromonas hydrophila infection. J World Aquacult Soc 2017; 48(2): 303-12. [http://dx.doi.org/10.1111/jwas. 12349]

[81] Yue GGL, Chan BCL, Hon PM, et al. Immunostimulatory activities of polysaccharide extract isolated from Curcuma longa. Intern J Biologic Macromolecules 2010; 47(3): 342-7

[http://dx.doi.org/10.1016/j.ijbiomac.2010.05.019] [PMID: 20609432]

[82] Dao TT, Nguyen PH, Won HK, Kim EH, Park J, et al. Curcuminoids from Curcuma longa and their inhibitory activities on influenza A neuraminidases. Food Chem 2012; 134: 21-8.

[http://dx.doi.org/10.1016/j.foodchem.2012.02.015]

[83] Kim HJ, Yoo HS, Kim JC, et al. Antiviral effect of Curcuma longa Linn extract against hepatitis B virus replication. J Ethnopharmacol 2009; 124(2): 189-96.

[http://dx.doi.org/10.1016/j.jep.2009.04.046] [PMID: 19409970]

[84] Ichsyani M, Ridhanya A, Risanti M, Desti H, Ceria R, et al. Antiviral effects of Curcuma longa L. against dengue virus in vitro and in vivo. IOP Conf Ser Earth Environ Sci 2017; 101012005

[http://dx.doi.org/10.1088/1755-1315/101/1/012005]

[85] Yoo JK, Lee JH, Cho HY, Kim JH. Change of antioxidant activities in carrots (Daucus carota var. sativa) with enzyme treatment. J Korean Soc Food Sci Nutr 2013; 42(2): 262-7.

[http://dx.doi.org/10.3746/jkfn.2013.42.2.262]

[86] Shakheel MB, Saliyan T, Satish S, Hedge K. Therapeutic uses of Daucus carota: A review. Intern J Pharma Chemic Res 2017; 3(2): 138-43.

[87] Prajna AS, Hegde K. Pharmacological health benefits of Daucus carota: A review. Interna J Pharma Chemic Res 2018; 4(2): 77-82.

[88] Torky ZA. Antiviral activity of polyphenols extracts from Daucus carota against Herpes simplex virus type 1. Online J Sci Technol 2013; 3(1): 20-32

[89] Brochot A, Guilbot A, Haddioui L, Roques C. Antibacterial, antifungal, and antiviral effects of three essential oil blends. MicrobiologyOpen 2017; 6(4)e459 [http://dx.doi.org/10.1002/mbo3.459] [PMID: 28296357]

[90] Miladi S, Abid N, Debarnoot C, Damak M, Canard B, et al. In vitro antiviral activities of extracts derived from Daucus maritimus seeds. Nat Prod Res 2011; 1-6. [PMID: 21895456]

[91] Al-Snafi AE. Nutritional and therapeutic importance of Daucus carota- a review. IOSR J Pharm 2017; 7(2): 72-88. [http://dx.doi.org/10.9790/3013-0702017288]

[92] Bhandari PR, Kamdod MA. Emblica officinalis (Amla): A review of potential therapeutic applications. Int J Green Pharm 2012; 6: 257-69. [http://dx.doi.org/10.4103/0973-8258.108204]

[93] Dasaroju S, Gottumukkala KM. Current trends in the research of Emblica officinalis (Amla): A pharmacological perspective. Int $\mathrm{J}$ Pharm Sci Rev Res 2014; 24(2): 150-9.

[94] Charmkar NK, Singh R. Emblica officinalis Gaertn. (Amla): A wonder gift of nature to humans. Int J Curr Microbiol Appl Sci 2017; 6(7): 4267-80.

[http://dx.doi.org/10.20546/ijcmas.2017.607.442]

[95] Hasan MR, Islam MN, Islam MR. Phytochemistry, pharmacological activities and traditional uses of Emblica officinalis: A review. Int Curr Pharm J 2016; 5(2): 14-21.

[http://dx.doi.org/10.3329/icpj.v5i2.26441]

[96] Estari M, Venkanna L, Sripriya D, Lalitha R. Human Immunodeficiency Virus (HIV-1) reverse transcriptase inhibitory activity of Phyllanthus emblica plant extract. Biology Medic 2012; 4(4): 178-82.

[97] Guardiola S, Mach N. [Therapeutic potential of Hibiscus sabdariffa: a review of the scientific evidence]. Endocrinol Nutr 2014; 61(5): 274-95.

[http://dx.doi.org/10.1016/j.endonu.2013.10.012] [PMID: 24444676]

[98] Da-Costa-Rocha I, Bonnlaender B, Sievers H, Pischel I, Heinrich M. Hibiscus sabdariffa L. - a phytochemical and pharmacological review. Food Chem 2014; 165: 424-43.

[http://dx.doi.org/10.1016/j.foodchem.2014.05.002]

[PMID: 25038696]

[99] Pacôme OA, Joseph DA, David NGJ, Hilaire KT. Some anthocyanins isolated and identified from petals and calyces of Hibiscus sabdariffa (Malvaceae). Intern J Herbal Medic 2019; 7(5): 12-8.

[100] Fakeye TO, Pal A, Bawankule DU, Khanuja SPS. Immunomodulatory effect of extracts of Hibiscus sabdariffa L. (Family Malvaceae) in a mouse model. Phytother Res 2008; 22(5): 664-8. [http://dx.doi.org/10.1002/ptr.2370] [PMID: 18398929]

[101] Nurkhasanah. The effect of rosella (Hibiscus sabdariffa 1) treatment on IL-10 and IL-14 secretion on Dimethylbenz (A) Anthracene (DMBA) induced rat. Int J Pharm Pharm Sci 2015; 7(4): 402-4. 
[102] Hussein ME, El Senousy AS, El-Askary HI, Mouneir SM, El-Fishawy AM. Immunomodulatory and anti-inflammatory activities of the defatted alcoholic extract and mucilage of Hibiscus sabdariffa L. leaves, and their chemical characterization. J Pharmacogn Phytochem 2019; 8(4): 982-90.

[103] Sunday OA, Munir AB, Akeeb OO, Bolanle AA, Badaru SO. Antiviral effect of Hibiscus sabdariffa and Celosia argentea on measles virus. Afr J Microbiol Res 2010; 4(4): 293-6.

[104] Hassan STS, Švajdlenka E, Berchová-Bímová K. Hibiscus sabdariffa L. and its bioactive constituents exhibit antiviral activity against HSV-2 and anti-enzymatic properties against urease by an ESI-MS based assay. Molecules 2017; 22(5): 722 .

[http://dx.doi.org/10.3390/molecules22050722] [PMID: 28468298]

[105] Takeda Y, Okuyama Y, Nakano H, et al. Antiviral activities of Hibiscus sabdariffa $L$. tea extract against Human Influenza A virus rely largely on acidic $\mathrm{pH}$ but partially on a low-pH-independent mechanism. Food Environ Virol 2020; 12(1): 9-19.

[http://dx.doi.org/10.1007/s12560-019-09408-x] [PMID: 31620998]

[106] Fitriana WD, Ersam T, Shimizu K, Fatmawati S. Antioxidant activity of Moringa oleifera extracts. Indones J Chem 2016; 16(3): 297-301. [http://dx.doi.org/10.22146/ijc.21145]

[107] Wright RJ, Lee KS, Hyacinth HI, et al. An investigation of the antioxidant capacity in extracts from Moringa oleifera plants grown in Jamaica. Plants 2017; 6(4): 48

[http://dx.doi.org/10.3390/plants6040048] [PMID: 29065510]

[108] Xu YB, Chen GL, Guo MQ. Antioxidant and anti-inflammatory activities of the crude extracts of Moringa oleifera from Kenya and their correlations with flavonoids. Antioxidants 2019; 8(8): 296. [http://dx.doi.org/10.3390/antiox8080296] [PMID: 31404978]

[109] Gupta R, Mathur M, Bajaj VK, et al. Evaluation of antidiabetic and antioxidant activity of Moringa oleifera in experimental diabetes. J Diabetes 2012; 4(2): 164-71.

[http://dx.doi.org/10.1111/j.1753-0407.2011.00173.x] [PMID: 22103446]

[110] Gupta A, Gautam MK, Singh RK, et al. Immunomodulatory effect of Moringa oleifera Lam. extract on cyclophosphamide induced toxicity in mice. Indian J Exp Biol 2010; 48(11): 1157-60.

[PMID: 21117458]

[111] Nfambi J, Bbosa GS, Sembajwe LF, Gakunga J, Kasolo JN. Immunomodulatory activity of methanolic leaf extract of Moringa oleifera in Wistar albino rats. J Basic Clin Physiol Pharmacol 2015; 26(6): 603-11.

[http://dx.doi.org/10.1515/jbcpp-2014-0104] [PMID: 26103628]

[112] Deshmukh P, Sharma RK, Sharma V, Jain P. Immunomodulatory activity of Moringa oleifera in albino rats. J Animal Res 2015; 5(2): $277-81$.

[http://dx.doi.org/10.5958/2277-940X.2015.00047.9]

[113] Bhattacheryya S. Chiranjib Banousodhi (Bengali) Part I and Part 2. Kolkata - 700009, India: Ananda Publishers Pvt. Ltd. 1977.

[114] Nasr-Eldin MA, Abdelhamid AG, Baraka DM. Antibiofilm and antiviral potential of leaf extracts from Moringa oleifera and Rosemary (Rosmarinus officinalis Lam.). Egypt J Microbiol 2017; 52: 129-39.

[115] Feustel S, Ayón-Pérez F, Sandoval-Rodriguez A, et al. Protective effects of Moringa oleifera on HBV genotypes $\mathrm{C}$ and $\mathrm{H}$ transiently transfected Huh7 cells. J Immunol Res 2017; 20176063850 [http://dx.doi.org/10.1155/2017/6063850] [PMID: 29214184]

[116] Chollom SC, Agada GOA, Gotep JG, Mwankon SE, Dus PC. Investigation of aqueous extract of Moringa oleifera Lam. seed for antiviral activity against Newcastle disease virus in ovo. J Med Plants Res 2012; 6(22): 3870-5.

[http://dx.doi.org/10.5897/JMPR12.394]

[117] Gilani AH, Jabeen Q, Khan MAU. A review of medicinal uses and pharmacological activities of Nigella sativa. Pak J Biol Sci 2004; 7(4): 441-51.

[http://dx.doi.org/10.3923/pjbs.2004.441.451]

[118] Ashraf SS, Rao MV, Kaneez FS, et al. Nigella sativa extract as a potent antioxidant for petrochemical-induced oxidative stress. J Chromatogr Sci 2011; 49(4): 321-6.

[http://dx.doi.org/10.1093/chrsci/49.4.321] [PMID: 21439125]

[119] Bordoni L, Fedeli D, Nasuti C, et al. Antioxidant and antiinflammatory properties of Nigella sativa oil in human pre-adipocytes. Antioxidants 2019; 8(2): 1-12.

[http://dx.doi.org/10.3390/antiox8020051] [PMID: 30823525]

[120] Haq A, Lobo PI, Al-Tufail M, Rama NR, Al-Sedairy ST. Immunomodulatory effect of Nigella sativa proteins fractionated by ion exchange chromatography. Int J Immunopharmacol 1999; 21(4):
283-95. [Cited in: Molla S, Azad MAK, Hasib MAZA, Hossain MM, Ahammed MS et al. A review on antiviral effects of Nigella sativa L. Pharmacology online newsletter 2019; 2: 47-53]

[http://dx.doi.org/10.1016/S0192-0561(99)00010-7] [PMID: 10408636]

[121] Sheir SK. Immunomodulatory and ameliorative role of Nigella sativa oil on schistosoma mansoni infected mice. Canadian J Pure Appl Sci 2015; 9: 3345-55. [Cited in: Molla S, Azad MAK, Hasib MAZA, Hossain MM, Ahammed MS et al. A review on antiviral effects of Nigella sativa L. Pharmacology online newsletter 2019; 2: 47-53].

[122] Onifade AA, Jewell AP, Adedeji WA. Nigella sativa concoction induced sustained seroreversion in HIV patient. Afr J Tradit Complement Altern Med 2013; 10(5): 332-5. [Cited in: Molla S, Azad MAK, Hasib MAZA, Hossain MM, Ahammed MS et al. A review on antiviral effects of Nigella sativa L. Pharmacology online newsletter 2019; 2: 47-53].

[http://dx.doi.org/10.4314/ajtcam.v10i5.18] [PMID: 24311845]

[123] Umar S, Munir MT, Subhan S, Azam T, Nisa Q, et al. Protective and antiviral activities of Nigella sativa against avian influenza (H9N2) in turkeys. J Saudi Soc Agric Sci 2016. [Cited in: Molla S, Azad MAK, Hasib MAZA, Hossain MM, Ahammed MS et al. A review on antiviral effects of Nigella sativa L. Pharmacology online newsletter 2019; 2: 47-53].

[http://dx.doi.org/10.1016/j.jssas.2016.09.004]

[124] Salem ML, Hossain MS. Protective effect of black seed oil from Nigella sativa against murine cytomegalovirus infection. Int $\mathrm{J}$ Immunopharmacol 2000; 22(9): 729-40. [Cited in: Molla S, Azad MAK, Hasib MAZA, Hossain MM, Ahammed MS et al. A review on antiviral effects of Nigella sativa L. Pharmacology online newsletter 2019; 2: 47-53].

[http://dx.doi.org/10.1016/S0192-0561(00)00036-9]

[PMID: 10884593]

[125] Salomi NJ, Nair SC, Jayawardhanan KK, Varghese CD, Panikkar KR. Antitumour principles from Nigella sativa seeds. Cancer Lett 1992; 63(1): 41-6. [Cited in: Molla S, Azad MAK, Hasib MAZA, Hossain MM, Ahammed MS et al. A review on antiviral effects of Nigella sativa L. Pharmacology online newsletter 2019; 2: 47-53].

[http://dx.doi.org/10.1016/0304-3835(92)90087-C] [PMID: 1555206]

[126] Worthen DR, Ghosheh OA, Crooks PA. The in vitro anti-tumor activity of some crude and purified components of blackseed, Nigella sativa L. Anticancer Res 1998; 18(3A): 1527-32. [Cited in: Molla S, Azad MAK, Hasib MAZA, Hossain MM, Ahammed MS et al. A review on antiviral effects of Nigella sativa L. Pharmacology online newsletter 2019; 2: 47-53]. [PMID: 9673365]

[127] Daba MH, Abdel-Rahman MS. Hepatoprotective activity of thymoquinone in isolated rat hepatocytes. Toxicol Lett 1998; 95(1): 23-9. [Cited in: Molla S, Azad MAK, Hasib MAZA, Hossain MM, Ahammed MS et al. A review on antiviral effects of Nigella sativa L. Pharmacology online newsletter 2019; 2: 47-53].

[http://dx.doi.org/10.1016/S0378-4274(98)00012-5] [PMID: 9650643]

[128] Nagi MN, Alam K, Badary OA, al-Shabanah OA, al-Sawaf HA, alBekairi AM. Thymoquinone protects against carbon tetrachloride hepatotoxicity in mice via an antioxidant mechanism. Biochem Mol Biol Int 1999; 47(1): 153-9. [Cited in: Molla S, Azad MAK, Hasib MAZA, Hossain MM, Ahammed MS et al. A review on antiviral effects of Nigella sativa L. Pharmacology online newsletter 2019; 2: 47-53].

[PMID: 10092955]

[129] Hussain EH, Jamil K, Rao M. Hypoglycaemic, hypolipidemic and antioxidant properties of tulsi (Ocimum sanctum linn) on streptozotocin induced diabetes in rats. Indian J Clin Biochem 2001; 16(2): 190-4.

[http://dx.doi.org/10.1007/BF02864859] [PMID: 23105316]

[130] Venuprasad MP, Hemanth Kumar K, Khanum F. Neuroprotective effects of hydroalcoholic extract of Ocimum sanctum against $\mathrm{H}_{2} \mathrm{O}_{2}$ induced neuronal cell damage in SH-SY5Y cells via its antioxidative defence mechanism. Neurochem Res 2013; 38(10): 2190-200. [http://dx.doi.org/10.1007/s11064-013-1128-7] [PMID: 23996399]

[131] Lavanya V, Ganapathy D, Visalakshi RM. Antioxidant and free radical scavenging activity of Ocimum basilicum - an in vitro study. Drug Invention Today 2019; 12(5): 1004-7.

[132] Jeba RC, Vaidyanathan R, Rameshkumar G. Immunomodulatory activity of aqueous extract of Ocimum sanctum in rat. Intern $\mathrm{J}$ Pharmaceut Biomedic Res 2011; 2(1): 33-8.

[133] Nahak G, Sahu RK. Immunostimulatory effect of Ocimum sanctum Linn. leaf extract in Clarias batrachus Linn. Asian J Pharm Clin Res 
2014; 7(3): 157-63.

[134] Das R, Raman RP, Saha H, Singh R. Effect of Ocimum sanctum Linn. (Tulsi) extract on the immunity and survival of Labeo rohita (Hamilton) infected with Aeromonas hydrophila. Aquacult Res 2015; 46: 1111-21.

[http://dx.doi.org/10.1111/are.12264]

[135] Yucharoen R, Anuchapreeda S, Tragoolpua Y. Anti-Herpes simplex virus activity of extracts from the culinary herbs Ocimum sanctum L., Ocimum basilicum L. and Ocimum americanum L. Afr J Biotechnol 2011; 10(5): 860-6.

[http://dx.doi.org/10.5897/AJB10.1351]

[136] Jayati Bhatia AK, Amit Kumar, Goel A, Gupta S, et al. In vitro antiviral potential of Ocimum sanctum leaves extract against New Castle disease virus of poultry. Intern J Microbiol Immunol Res 2013; 2(7): 51-5.

[137] Ghoke SS, Sood R, Kumar N, et al. Evaluation of antiviral activity of Ocimum sanctum and Acacia arabica leaves extracts against H9N2 virus using embryonated chicken egg model. BMC Complement Altern Med 2018; 18(1): 174.

[http://dx.doi.org/10.1186/s12906-018-2238-1] [PMID: 29866088]

[138] Verma S. Chemical constituents and pharmacological action of Ocimum sanctum (Indian holy basil-Tulsi). J Phytopharmacology 2016; 5(5): 205-7.

[139] Rao PS, Navinchandra S, Jayaveera KN. An important spice, Pimenta dioica (Linn.) Merill: a review. Int Curr Pharm J 2012; 1(8): 221-5. [http://dx.doi.org/10.3329/icpj.vli8.11255]

[140] Onwasigwe EN, Verghese M, Sunkara R, Shackelford L, Walker LT. In vitro analysis of the antioxidant effect of allspice. Food Nutr Sci 2017; 8: 778-92.

[http://dx.doi.org/10.4236/fns.2017.87055]

[141] Milenković A, Stanojević J, Radić ZS, Pejčić M, Cvetković D, et al. Chemical composition, antioxidative and antimicrobial activity of allspice (Pimenta dioica (L.) Merr. essential oil and extract. Advanced technologies 2020; 9(1): 27-36.

[142] Zhang L, Lokeshwar BL. Medicinal properties of the Jamaican pepper plant Pimenta dioica and Allspice. Curr Drug Targets 2012; 13(14): 1900-6.

[http://dx.doi.org/10.2174/138945012804545641] [PMID: 23140298]

[143] Gullu K, Acar U, Kesbic OS, Yilmaz S, Agdamar S, et al. Beneficial effects of oral allspice, Pimenta dioica powder supplementation on the hemato-immunological and serum biochemical responses of Oreochromis mossambicus. Aquacult Res 2015; 2015: 1-8. [http://dx.doi.org/10.1111/are.12717]

[144] Badmanaban R, Banji D, Sen DJ, Retheesh G. Nice holistic flora allspice needs not to pay much more price in spice. World $\mathrm{J}$ Pharmaceut Life Sci 2018; 4(1): 63-71.

[145] Gilling DH, Kitajima M, Torrey JR, Bright KR. Mechanisms of antiviral action of plant antimicrobials against murine norovirus. Appl Environ Microbiol 2014; 80(16): 4898-910.

[http://dx.doi.org/10.1128/AEM.00402-14] [PMID: 24907316]

[146] Dinesha R, Chikkanna D. Antioxidant activities of Pippali (Piper longum) proteins. Int J Pharm Drug Anal 2014; 2(11): 811-4.

[147] Archana D, Dixitha M, Santhy KS. Antioxidant and anti-clastogenic potential of Piper longum L. Int J App Pharm 2015; 7(2): 11-4.

[148] Osmangani HM, Hoq MO, Tamanna T. Ethnomedicinal, phytochemical and pharmacological properties of Piper longum (Linn). Asian J Med Biol Res 2019; 5(1): 1-7.

[http://dx.doi.org/10.3329/ajmbr. v5i1.41038]

[149] Chauhan K, Solanki R, Patel A, Macwan C, Patel M. Phytochemical and therapeutic potential of Piper longum Linn. a review. Int J Res Ayurveda Pharm 2011; 2(1): 157-61.

[150] Kumar S, Kamboj J, Suman, Sharma S. Overview for various aspects of the health benefits of Piper longum linn. fruit. J Acupunct Meridian Stud 2011; 4(2): 134-40.

[http://dx.doi.org/10.1016/S2005-2901(11)60020-4] [PMID: 21704957]

[151] Priya NC. SaravanaKumari P. Antiviral activities and cytotoxicity assay of seed extracts of Piper longum and Piper nigrum on Human cell lines. Int J Pharm Sci Rev Res 2017; 44(1): 197-02.

[152] Gülçin I. The antioxidant and radical scavenging activities of black pepper (Piper nigrum) seeds. Int J Food Sci Nutr 2005; 56(7): 491-9. [http://dx.doi.org/10.1080/09637480500450248] [PMID: 16503560]

[153] Damanhouri ZA, Ahmad A. A review on therapeutic potential of Piper nigrum L. (Black Pepper): the king of spices. Med Aromat Plants 2014; 3(3)1000161

[http://dx.doi.org/10.4172/2167-0412.1000161]

[154] Radi'c ZS. Piperine - a major principle of black pepper: A review of its bioactivity and studies. Appl Sci (Basel) 2019; 9(4270): 1-29. [http://dx.doi.org/10.3390/app9204270]

[155] Sarker MMR. Induction of humoral immunity through the enhancement of IgM production in murine splenic cells by ethanolic extract of seed of Piper nigrum L. J Sci Res 2012; 4(3): 751-56.

[156] Mohamed MSN, Jaikumar K, Anand D, Saravanan P. Assessment of cytotoxic and immunomodulatory properties of Piper nigrum Linn. (White pepper) seed extract. Int J Pharm Sci Drug Res 2017; 9(2): 64-7.

[157] Mair CE, Liu R, Atanasov AG, Schmidtke M, Dirsch VM, Rollinger JM. Antiviral and anti-proliferative in vitro activities of piperamides from black pepper. Planta Medica 2016; 81(S 01): S1-S381.

[158] Nag A, Chowdhury RR. Piperine, an alkaloid of black pepper seeds can effectively inhibit the antiviral enzymes of Dengue and Ebola viruses, an in silico molecular docking study. Virus Dis 2020; pp. 19-26.

[159] Bozin B, Mimica-Dukic N, Samojlik I, Jovin E. Antimicrobial and antioxidant properties of rosemary and sage (Rosmarinus officinalis $\mathrm{L}$. and Salvia officinalis L., Lamiaceae) essential oils. J Agric Food Chem 2007; 55(19): 7879-85.

[http://dx.doi.org/10.1021/jf0715323] [PMID: 17708648]

[160] Rašković A, Milanović I, Pavlović N, Ćebović T, Vukmirović S, Mikov M. Antioxidant activity of rosemary (Rosmarinus officinalis L.) essential oil and its hepatoprotective potential. BMC Complement Altern Med 2014; 14: 225.

[http://dx.doi.org/10.1186/1472-6882-14-225] [PMID: 25002023]

[161] Ghozlan SA, El-Far AH, Sadek KM, Abourawash AA, Abdel-Latif MA. Effect of Rosemary (Rosmarinus Officinalis) dietary supplementation in broiler chickens concerning immunity, antioxidant status, and performance. Alex J Vet Sci 2017; 55(1): 152-61. [http://dx.doi.org/10.5455/ajvs.275350]

[162] Gültepe N, Bilen S, Yılmaz S, Güroy D, Aydın S. Effects of herbs and spice on health status of tilapia (Oreochromis mossambicus) challenged with Streptococcus iniae. Acta Vet Brno 2014; 83: 125-31. [http://dx.doi.org/10.2754/avb201483020125]

[163] Shokrollahi B, Amini F, Fakour S, Andi MA. Effect of rosemary (Rosmarinus officinalis) extract on weight, hematology and cellmediated immune response of newborn goat kids. J Agric Rural Dev Trop Subtrop 2015; 116(1): 91-7.

[164] Ayoub HF, Tantawy MME, Latif HMRA. Influence of Moringa (Moringa oleifera) and Rosemary (Rosmarinus officinalis), and Turmeric (Curcuma longa) on immune parameters and challenge of Nile tilapia to Aeromonas hydrophila. Life Sci J 2019; 16(4): 8-15.

[165] Al-Megrin WA, AlSadhan NA, Metwally DM, Al-Talhi RA, ElKhadragy MF, Abdel-Hafez LJM. Potential antiviral agents of Rosmarinus officinalis extract against herpes viruses 1 and 2. Biosci Rep 2020; 40(6)BSR20200992

[http://dx.doi.org/10.1042/BSR20200992] [PMID: 32469389]

[166] Schütz K, Carle R, Schieber A. Taraxacum--a review on its phytochemical and pharmacological profile. J Ethnopharmacol 2006; 107(3): 313-23.

[http://dx.doi.org/10.1016/j.jep.2006.07.021] [PMID: 16950583]

[167] Choi UK, Lee OH, Yim JH, et al. Hypolipidemic and antioxidant effects of dandelion (Taraxacum officinale) root and leaf on cholesterol-fed rabbits. Int J Mol Sci 2010; 11(1): 67-78. [http://dx.doi.org/10.3390/ijms11010067] [PMID: 20162002]

[168] Aremu OO, Oyedeji AO, Oyedeji OO, Nkeh-Chungag BN, Rusike CRS. In vitro and in vivo antioxidant properties of Taraxacum officinale in Nw-Nitro-L-Arginine Methyl Ester (L-NAME)-induced hypertensive rats. Antioxidants 2019; 8(8): 309.

[http://dx.doi.org/10.3390/antiox8080309] [PMID: 31443195]

[169] Kim J, Choi G, Hwang H, Ku H. Characterization of immunostimulatory activities of fractions obtained from Taraxacum officinale. Planta Med 2010; 76: 12.

[http://dx.doi.org/10.1055/s-0030-1264719]

[170] Kasianningsih S, Rivanti E, Pratama RH, Pratama NR, Ikawati M, Meiyanto E. Taraxacum officinale leaves ethanolic extract as immunostimulatory agent for reducing side effect of doxorubicin in Sprague dawley rats. Indones J Cancer Chemoprevent 2011; 2(1): 135-40.

[http://dx.doi.org/10.14499/indonesianjcanchemoprev2iss1pp135-140]

[171] Wirngo FE, Lambert MN, Jeppesen PB. The physiological effects of Dandelion (Taraxacum officinale) in type 2 diabetes. Rev Diabet Stud 2016; 13(2-3): 113-31.

[http://dx.doi.org/10.1900/RDS.2016.13.113] [PMID: 28012278]

[172] He W, Han H, Wang W, Gao B. Anti-influenza virus effect of aqueous extracts from dandelion. Virol J 2011; 8: 538. 
[http://dx.doi.org/10.1186/1743-422X-8-538] [PMID: 22168277]

[173] Rehman S, Ijaz B, Fatima N, Muhammad SA, Riazuddin S. Therapeutic potential of Taraxacum officinale against HCV NS5B polymerase: In-vitro and In silico study. Biomed Pharmacother 2016; 83: 881-91.

[http://dx.doi.org/10.1016/j.biopha.2016.08.002] [PMID: 27513212]

[174] Flores-Ocelotl MR, Rosas-Murrieta NH, Moreno DA, et al. Taraxacum officinale and Urtica dioica extracts inhibit dengue virus serotype 2 replication in vitro. BMC Complement Altern Med 2018; 18(1): 95 .

[http://dx.doi.org/10.1186/s12906-018-2163-3] [PMID: 29548293]

[175] Lis B, Olas B. Pro-health activity of dandelion (Taraxacum officinale L.) and its food products - history and present. J Funct Foods 2019; 59: $40-8$

[http://dx.doi.org/10.1016/j.jff.2019.05.012]

[176] Mahesh R. Begum VMH. Antioxidant effect of Terminalia chebula aqueous extract on age-related oxidative stress in heart. Iranian J Pharmacol Therapeut 2007; 6: 197-01.

[177] Vaghela JS, Sisodia SS. In vitro antioxidant activity of Terminalia chebula fruit extracts. Research J Pharm Tech 2011; 4(12): 1835-43.

[178] Sarwar S, Malik AH, Rahman MA, Rahman MZ, Rana MS. Antioxidant, cytotoxic and analgesic activities of the methanolic fruit extract of Terminalia chebula Retz. Int Curr Pharm J 2013; 3(1): 219-22

[http://dx.doi.org/10.3329/icpj.v3i1.17296]

[179] Shivaprasad HN, Kharya MD, Rana AC, Mohan S. Preliminary immunomodulatory activities of the aqueous extract of Terminalia chebula. Pharm Biol 2006; 44(1): 32-4.

[http://dx.doi.org/10.1080/13880200500530542]

[180] Aher V, Wahi AK. Immunomodulatory activity of alcohol extract of Terminalia chebula Retz. Combretaceae. Trop J Pharm Res 2011; 10(5): $567-75$.

[http://dx.doi.org/10.4314/tjpr.v10i5.5]

[181] Tewari D, Mocan A, Parvanov ED, et al. Ethnopharmacological approaches for therapy of jaundice: part II. Highly used plant species from Acanthaceae, Euphorbiaceae, Asteraceae, Combretaceae and Fabaceae Families. Front Pharmacol 2017; 8: 519.

[http://dx.doi.org/10.3389/fphar.2017.00519] [PMID: 28848436]

[182] Lin LT, Chen TY, Lin SC, et al. Broad-spectrum antiviral activity of chebulagic acid and punicalagin against viruses that use glycosaminoglycans for entry. BMC Microbiol 2013; 13: 187. [http://dx.doi.org/10.1186/1471-2180-13-187] [PMID: 23924316]

[183] Xie F. Broad-spectrum antiviral effect of chebulagic acid and punicalagin on respiratory syncytial virus infection in a BALB/c model. Int J Clin Exp Pathol 2016; 9(2): 611-9.

[184] Kesharwani A, Polachira SK, Nair R, Agarwal A, Mishra NN, Gupta SK. Anti-HSV-2 activity of Terminalia chebula Retz extract and its constituents, chebulagic and chebulinic acids. BMC Complement Altern Med 2017; 17(1): 110.

[http://dx.doi.org/10.1186/s12906-017-1620-8] [PMID: 28196487]

[185] Chattopadhyay RR, Bhattacharyya SK. Terminalia chebula: An update. Pharmacogn Rev 2007; 1(1): 151-6.

[186] Kulisic T, Radonic A, Milos M. Antioxidant properties of thyme (Thymus vulgaris L.) and wild thyme (Thymus serpyllum L.) essential oils. Ital J Food Sci 2005; 3(17): 1-10.

[187] El-Nekeety AA, Mohamed SR, Hathout AS, Hassan NS, Aly SE, Abdel-Wahhab MA. Antioxidant properties of Thymus vulgaris oil against aflatoxin-induce oxidative stress in male rats. Toxicon 2011; 57(7-8): 984-91

[http://dx.doi.org/10.1016/j.toxicon.2011.03.021] [PMID: 21477612]

[188] Gedikoğlu A, Sökmen M, Çivit A. Evaluation of Thymus vulgaris and Thymbra spicata essential oils and plant extracts for chemical composition, antioxidant, and antimicrobial properties. Food Sci Nutr 2019; 7(5): 1704-14.

[http://dx.doi.org/10.1002/fsn3.1007] [PMID: 31139383]

[189] Saki AA, Kalantar M, Khoramabadi V. Effects of drinking thyme essence (Thymus vulgaris L.) on growth performance, immune response and intestinal selected bacterial population in broiler chickens. Poult Sci J 2014; 2(2): 113-23.

[190] Zadmajid V, Mohammadi C. Dietary thyme essential oil (Thymus vulgaris) changes serum stress markers, enzyme activity, and hematological parameters in gibel carp (Carassius auratus gibelio) exposed to silver nanoparticles. Iran J Fish Sci 2017; 16(3): 1063-84.

[191] AL-Faragi JK. Influence of thyme (Thymus vulgaris) as feed additives on growth performance and antifungal activity on Saprolegnia spp. in Cyprinus carpio L. J Entomol Zool Stud 2017; 5(6): 1598-02.

[192] Rezatofighi SE, Seydabadi A, Seyyed Nejad SM. Evaluating the efficacy of Achillea millefolium and Thymus vulgaris extracts against Newcastle Disease virus in ovo. Jundishapur J Microbiol 2014; $7(2) \mathrm{e} 9016$

[http://dx.doi.org/10.5812/jjm.9016] [PMID: 25147678]

[193] Vimalanathan S, Hudson J. Anti-influenza virus activity of essential oils and vapors. Americ J Essential Oils Natural Products 2014; 2(1): 47-53.

[194] Kaewprom K, Chen TH, Lin CF, Chiou MT, Lin CN. Antiviral activity of Thymus vulgaris and Nepeta cataria hydrosols against porcine reproductive and respiratory syndrome virus. Wetchasan Sattawaphaet 2017; 47(1): 25-33.

[195] Dauqan EMA, Abdullah A. Medicinal and functional values of thyme (Thymus vulgaris L.). Herb J App Biol Biotech 2017; 5(02): 17-22. [http://dx.doi.org/10.7324/JABB.2017.50203]

[196] Subramanian M, Chintalwar GJ, Chattopadhyay S. Antioxidant properties of a Tinospora cordifolia polysaccharide against ironmediated lipid damage and gamma-ray induced protein damage. Redox Rep 2002; 7(3): 137-43.

[http://dx.doi.org/10.1179/135100002125000370] [PMID: 12189043]

[197] Sarala M, Velu V, Anandharamakrishnan C, Singh RP. Spray drying of Tinospora cordifolia leaf and stem extract and evaluation of antioxidant activity. J Food Sci Technol 2012; 49(1): 119-22.

[http://dx.doi.org/10.1007/s13197-011-0364-6] [PMID: 23572835]

[198] Upadhyay N, Ganie SA, Agnihotri RK, Sharma R. Studies on antioxidant activity and total phenolic content of Tinospora cordifolia (Miers.) stem using in vitro models. Americ J Phytomedic Clinic Therapeutics 2013; 1(8): 617-27.

[199] More P, Pai K. Immunomodulatory effects of Tinospora cordifolia (Guduchi) on macrophage activation. Biology Medic 2011; 3(2): 134-40.

[200] Aranha I, Clement F, Venkatesh YP. Immunostimulatory properties of the major protein from the stem of the Ayurvedic medicinal herb, guduchi (Tinospora cordifolia). J Ethnopharmacol 2012; 139(2): 366-72.

[http://dx.doi.org/10.1016/j.jep.2011.11.013] [PMID: 22119223]

[201] Dissanayake KGC, Perera WPRT, Premasinghe N. Immunomodulatory efficiency of Tinospora cordifolia against viral infections. World J Pharmaceut Medic Res 2020; 6(5): 22-8.

[202] Pruthvish R, Gopinatha SM. Antiviral prospective of Tinospora cordifolia on HSV-1. Int J Curr Microbiol Appl Sci 2018; 7(01): 3617-24.

[http://dx.doi.org/10.20546/ijcmas.2018.701.425]

[203] Sachan S, Dhama K, Latheef SK, Samad HA, Mariappan AK, et al. Immunomodulatory Potential of Tinospora cordifolia and $\mathrm{CpG}$ ODN (TLR21 agonist) against the very virulent. Infectious Bursal Disease virus in SPF Chicks Vaccines 2019; 7: 106.

[http://dx.doi.org/10.3390/vaccines7030106]

[204] Samad NB, Debnath T, Ye M, Hasnat MA, Lim BO. In vitro antioxidant and anti-inflammatory activities of Korean blueberry (Vaccinium corymbosum L.) extracts. Asian Pac J Trop Biomed 2014; 4(10): 807-15.

[http://dx.doi.org/10.12980/APJTB.4.2014C1008]

[205] Kraujalytė V, Venskutonis PR, Pukalskas A, Česonienė L, Daubaras R. Antioxidant properties, phenolic composition and potentiometric sensor array evaluation of commercial and new blueberry (Vaccinium corymbosum) and bog blueberry (Vaccinium uliginosum) genotypes. Food Chem 2015; 188: 583-90.

[http://dx.doi.org/10.1016/j.foodchem.2015.05.031] 26041234]

[206] Kalt W, Cassidy A, Howard LR, et al. Recent research on the health benefits of blueberries and their anthocyanins. Adv Nutr 2020; 11(2): 224-36.

[http://dx.doi.org/10.1093/advances/nmz065] [PMID: 31329250]

[207] Jeong DY, Yang HJ, Jeong SJ, Kim MG, Yun CY Immunostimulatory effects of blueberry yeast fermented powder against Cyclophosphamide -induced immunosuppressed model. J Physiol Pathol Korean Med 2019; 33(1): 48-55. [http://dx.doi.org/10.15188/kjopp.2019.02.33.1.48]

[208] Sanhueza DP, Blancheteau CI, Fonseca AR, Díaz MR. Anthocyanins in berries and their potential use in human health. IntechOpen 2017. [http://dx.doi.org/10.5772/67104]

[209] Erasto P, Grierson DS, Afolayan AJ. Evaluation of antioxidant activity and the fatty acid profile of the leaves of Vernonia amygdalina growing in South Africa. Food Chem 2007; 104(2): 636-42. [http://dx.doi.org/10.1016/j.foodchem.2006.12.013]

[210] Farombi EO, Owoeye O. Antioxidative and chemopreventive properties of Vernonia amygdalina and Garcinia biflavonoid. Int $\mathrm{J}$ 
Environ Res Public Health 2011; 8(6): 2533-55.

[http://dx.doi.org/10.3390/ijerph8062533] [PMID: 21776245]

[211] Omede A, Suleiman MS, Atanu FO, Sheneni VD, Jegede ER. Evaluation of antioxidant and cytotoxic properties of Vernonia amygdalina. Int J Plant Stu 2018; 1(1): 1-6.

[212] Momoh MA, Muhamed U, Agboke AA, Akpabio EI, Osonwa UE. Immunological effect of aqueous extract of Vernonia amygdalina and a known immune booster called immunace $(\circledR)$ and their admixtures on HIV/AIDS clients: a comparative study. Asian Pac J Trop Biomed 2012; 2(3): 181-4.

[http://dx.doi.org/10.1016/S2221-1691(12)60038-0] [PMID: 23569894]

[213] Akpan HD, Ekaidem I. Modulation of immunological and hematological disturbances of Diabetes mellitus by diets containing combined leaves of Vernonia amygdalina and Gongronema latifolium. Br J Appl Sci Technol 2015; 6(5): 534-44 [http://dx.doi.org/10.9734/BJAST/2015/14266]

[214] Setiawan LTK, Nugraha J, Lestari P, Sinansari R, Soegianto L. Effect of African leaf (Vernonia amygdalina) to IL-6 and IL-10 level on Staphylococcus aureus infection. Indonesian J Tropical Infecti Dis 2019; 7(4): 69-74.

[http://dx.doi.org/10.20473/ijtid.v7i4.9654]

[215] Yeap SK, Ho WY, Beh BK, Liang WS, Ky H, et al. Vernonia amygdalina, an ethnoveterinary and ethnomedical used green vegetable with multiple bioactivities. J Med Plants Res 2010; 4(25): 2787-12.

[216] Laila U, Akram M, Shariati MA, et al. Role of medicinal plants in HIV/AIDS therapy. Clin Exp Pharmacol Physiol 2019; 46(12): 1063-73.

[http://dx.doi.org/10.1111/1440-1681.13151] [PMID: 31365763]

[217] Alara OR, Abdurahman NH, Mudalip SKA, Olalere OA. Phytochemical and pharmacological properties of Vernonia amygdalina: a review. J Chemical Engineering Industrial Biotech 2017; 2: 80-96.

[http://dx.doi.org/10.15282/jceib.v2i1.3871]

[218] Alam N, Hossain M, Mottalib MA, Sulaiman SA, Gan SH, Khalil MI. Methanolic extracts of Withania somnifera leaves, fruits and roots possess antioxidant properties and antibacterial activities. BMC Complement Altern Med 2012; 12: 175.

[http://dx.doi.org/10.1186/1472-6882-12-175] [PMID: 23039061]

[219] Ansari AQ, Ahmed SA, Waheed MA, Juned AS. Extraction and determination of antioxidant activity of Withania somnifera Dunal. Eur J Exp Biol 2013; 3(5): 502-7.

[220] Paul RK, Kabir H, Chowdhury UK, Rahaman MS, Ahmad MF. In vitro antioxidant activity of Withania somnifera root. Intern J Advan Res Chemic Sci 2016; 3(3): 45-56.

[221] Gupta GL, Rana AC. Withania somnifera (Ashwagandha): A review. Pharmacogn Rev 2007; 1(1): 129-36.

[222] Kumar S, Gautam PK, Acharya A. Aqueous extract of Withania somnifera (Ashwagandha) root an indigenous medicinal plant enhances antigen specific Cell-Mediated Immune Response (CMIR) in $\mathrm{T}$ cell lymphoma. Intern J Advanced Res Engineering Applied Sci 2015; 4(8): 12-28.

[223] Mukherjee D, Ghosal I, Moniruzzaman M, De M, Chakraborty SB. Dietary administration of ethanol and methanol extracts of Withania somnifera root stimulates innate immunity, physiological parameters and growth in Nile Tilapia Oreochromis niloticus. Ribarstvo 2019; 77: 106-17.

[http://dx.doi.org/10.2478/cjf-2019-0012]

[224] Kambizi L, Goosen BM, Taylor MB, Afolayan AJ. Anti-viral effects of aqueous extracts of Aloe ferox and Withania somnifera on Herpes simplex virus type 1 in cell culture. S Afr J Sci 2007; 103: 359-60.

[225] Grover A, Agrawal V, Shandilya A, Bisaria VS, Sundar D. Nonnucleosidic inhibition of Herpes simplex virus DNA polymerase: mechanistic insights into the anti-herpetic mode of action of herbal drug withaferin A. BMC Bioinformatics 2011; 12(Suppl. 13): S22. [http://dx.doi.org/10.1186/1471-2105-12-S13-S22] [PMID: 22373101]

[226] Ganguly B, Umapathi V, Rastogi SK. Nitric oxide induced by Indian ginseng root extract inhibits Infectious Bursal Disease virus in chicken embryo fibroblasts in vitro. J Anim Sci Technol 2018; 60: 2.

[http://dx.doi.org/10.1186/s40781-017-0156-2] [PMID: 29340165]

[227] Singh N, Verma P, Pandey BR, Gilca M. Role of Withania somnifera in prevention and treatment of Cancer: An overview. Int J Pharm Sci Drug Res 2011;3(4): 274-9.

[228] Bharti VK, Malik JK, Gupta RC. Ashwangandha: Multiple health benefits. In: Chapter 52, Nutraceuticals - efficacy, safety and toxicity. 2016; pp. 717-33.
[229] Kabuto H, Nishizawa M, Tada M, Higashio C, Shishibori T, Kohno M. Zingerone [4-(4-hydroxy-3-methoxyphenyl)-2-butanone] prevents 6-hydroxydopamine-induced dopamine depression in mouse striatum and increases superoxide scavenging activity in serum. Neurochem Res 2005; 30(3): 325-32.

[http://dx.doi.org/10.1007/s11064-005-2606-3] [PMID: 16018576]

[230] Mao QQ, Xu XY, Cao SY, et al. Bioactive compounds and bioactivities of ginger (Zingiber officinale Roscoe). Foods 2019; 8(6): $1-21$.

[http://dx.doi.org/10.3390/foods8060185] [PMID: 31151279]

[231] Haghighi M, Rohani MS. The effects of powdered ginger (Zingiber officinale) on the hematological and immunological parameters of rainbow trout Oncorhynchus mykiss. J Med Pant Herbal Therapy Res 2013; 1: 8-12.

[232] Shakya SR. Medicinal uses of ginger (Zingiber officinale Roscoe) improves growth and enhances immunity in aquaculture. Intern J Chemic Studies 2015; 3(2): 83-7.

[233] Dissanayake KGC, Waliwita WALC, Liyanage RP. A review on medicinal uses of zingiber officinale (ginger). Int J Health Sci Res 2020; 10(6): 142-8.

[234] Ishiguro K, Ando $\mathrm{T}$, Maeda $\mathrm{O}$, et al. Ginger ingredients reduce viability of gastric cancer cells via distinct mechanisms. Biochem Biophys Res Commun 2007; 362(1): 218-23.

[http://dx.doi.org/10.1016/j.bbrc.2007.08.012] [PMID: 17706603]

[235] Sung B, Jhurani S, Ahn KS, et al. Zerumbone down-regulates chemokine receptor CXCR4 expression leading to inhibition of CXCL12-induced invasion of breast and pancreatic tumor cells. Cancer Res 2008; 68(21): 8938-44.

[http://dx.doi.org/10.1158/0008-5472.CAN-08-2155]

[PMID: 18974138

[236] Hung JY, Hsu YL, Li CT, et al. 6-Shogaol, an active constituent of dietary ginger, induces autophagy by inhibiting the AKT/mTOR pathway in human non-small cell lung cancer A549 cells. J Agric Food Chem 2009; 57(20): 9809-16.

[http://dx.doi.org/10.1021/jf902315e] [PMID: 19799425]

[237] El-Wahab AA, El-Adawi H, El-Demellawy M. In-vitro study of the antiviral activity of Zingiber Officinale. Planta Med 2009; 75: PF7. [http://dx.doi.org/10.1055/s-0029-1234649]

[238] Chang JS, Wang KC, Yeh CF, Shieh DE, Chiang LC. Fresh ginger (Zingiber officinale) has anti-viral activity against human respiratory syncytial virus in human respiratory tract cell lines. J Ethnopharmacol 2013; 145(1): 146-51.

[http://dx.doi.org/10.1016/j.jep.2012.10.043] [PMID: 23123794]

[239] Aboubakr HA, Nauertz A, Luong NT, et al. In vitro antiviral activity of clove and ginger aqueous extracts against feline calcivirus, a surrogate for human norovirus. J Food Prot 2016; 79(6): 1001-12. [http://dx.doi.org/10.4315/0362-028X.JFP-15-593] [PMID: 27296605]

[240] Yemitan OK, Izegbu MC. Protective effects of Zingiber officinale (Zingiberaceae) against carbon tetrachloride and acetaminopheninduced hepatotoxicity in rats. Phytother Res 2006; 20(11): 997-1002. [http://dx.doi.org/10.1002/ptr.1957] [PMID: 16941609]

[241] Schipani S. How to make your own fruit and vegetable wash with a few simple ingredients. 2019. Available from https://hellohomestead.com/how-to-make-your-own-fruit-and-vegetabl e-wash-with-a-few-simple-ingredients/

[242] Miguel AC, Costa MJ, Rivera MC, Ramos OL, Vicente AA. Flavoring and coating technologies for preservation and processing of foods. In: Conventional and advanced food processing technologies (Chapter 12) 1st edn. Suvendu Bhattacharya. John Wiley \& Sons, Ltd 2015.

[243] Ebrahimi M, Khosravi-Darani K. Essential oils as natural food preservatives: Antimicrobial and antioxidant applications. In: Doughari J, Ed. Antimicrobials from nature: effective control agents for drug resistant pathogens. 37/661 (2), Fort P.O. Trivandrum - 695 023, Kerala, India: Transworld research network 2013.

[244] Wandrey C, Bartkowiak A, Harding SE. Materials for encapsulation. In: Zuidam NJ, Nedovie VA, Eds. Encapsulation technologies for active food ingredients and food processing. Springer Science, LLC 2010.

[http://dx.doi.org/10.1007/978-1-4419-1008-0 3]

[245] Singh RP, McLellan MR. Fruit processing Encyclopaedia Britannica, Inc 2016. Available from: https://www.britannica.com/topic/fruit-processing

[246] Zweig SE. Advances in vaccine stability monitoring technology. Vaccine 2006. Available from: www.sciencedirect.com10.1016/j.vaccine.2006.05.007

[247] WHO. What is VVM and how does it work? What is VVM and how does it work? Available from: https://www.who.int 
[248] Kartoglu U. WHO, UNICEF urge use of vaccine vial monitors 2007. Available from:

www.healio.com/infectious-disease/vaccine-preventable-diseases/new s/print/infectious-disease-news/\%7B56d61fc7-6265-4cb3-9b6e $828699 \mathrm{c} 1 \mathrm{~b} 804 \% 7 \mathrm{D} /$ whounicef-urge-use-of-vaccine-vial-monitors
[249] Pattanayak S. Use of 'Vaccine Vial Monitor' in all animal and bird vaccines - a demand of the day. Explor Anim Med Res 2013; 3(1) 5-6.

[250] PQS performance specification (WHO/PQS/E06/IN05.1). 2006. Available from: https:/ www.unicef.org/videoaudio/PDFs/Annex_B_-_WHO_VVM.pdf

\section{C) 2021 Shibabrata Pattanayak}

This is an open access article distributed under the terms of the Creative Commons Attribution 4.0 International Public License (CC-BY 4.0), a copy of which is available at: https://creativecommons.org/licenses/by/4.0/legalcode. This license permits unrestricted use, distribution, and reproduction in any medium, provided the original author and source are credited. 